\title{
Article \\ An Eco-Friendly Approach to the Control of Pathogenic Microbes and Anopheles stephensi Malarial Vector Using Magnesium Oxide Nanoparticles (Mg-NPs) Fabricated by Penicillium chrysogenum
}

\author{
Amr Fouda 1,*(D), Mohamed A. Awad 2 (D), Ahmed M. Eid 1므, Ebrahim Saied ${ }^{1}$, Mohammed G. Barghoth ${ }^{1}$, \\ Mohammed F. Hamza ${ }^{3,4}\left(\mathbb{D}\right.$, Mohamed F. Awad ${ }^{5}$ (D) Salah Abdelbary ${ }^{1}$ and Saad El-Din Hassan ${ }^{1, *(\mathbb{D})}$
}

1 Department of Botany and Microbiology, Faculty of Science, Al-Azhar University, Nasr City, Cairo 11884, Egypt; aeidmicrobiology@azhar.edu.eg (A.M.E.); hema_almassry2000@azhar.edu.eg (E.S.); mohamed_gamal.sci@azhar.edu.eg (M.G.B.); abdelbary_salah@azhar.edu.eg (S.A.)

2 Department of Zoology and Entomology, Faculty of Science, Al-Azhar University, Nasr City, Cairo 11884,Egypt; Mohamed_awad@azhar.edu.eg

3 Guangxi Key Laboratory of Processing for Non-Ferrous Metals and Featured Materials, School of Resources, Environment and Materials, Guangxi University, Nanning 530004, China; m_fouda21@hotmail.com

4 Nuclear Materials Authority, El-Maadi, Cairo POB 530, Egypt

check for updates

Citation: Fouda, A.; Awad, M.A.; Eid, A.M.; Saied, E.; Barghoth, M.G.; Hamza, M.F.; Awad, M.F.; Abdelbary, S.; Hassan, S.E.-D. An Eco-Friendly Approach to the Control of Pathogenic Microbes and Anopheles stephensi Malarial Vector Using Magnesium Oxide Nanoparticles (Mg-NPs) Fabricated by Penicillium chrysogenum. Int. J. Mol. Sci. 2021, 22, 5096. https://doi.org/10.3390/ ijms22105096

Academic Editor: Pavel Rossner

Received: 18 April 2021

Accepted: 8 May 2021

Published: 12 May 2021

Publisher's Note: MDPI stays neutral with regard to jurisdictional claims in published maps and institutional affiliations.

Copyright: (c) 2021 by the authors. Licensee MDPI, Basel, Switzerland. This article is an open access article distributed under the terms and conditions of the Creative Commons Attribution (CC BY) license (https:/ / creativecommons.org/licenses/by/ $4.0 /)$.
5 Department of Biology, College of Science, Taif University, P.O. Box 11099, Taif 21944, Saudi Arabia; m.fadl@tu.edu.sa

* Correspondence: amr_fh83@azhar.edu.eg (A.F.); Saad.el-din.hassan@umontreal.ca (S.E.-D.H.); Tel.: +20-111-3351244 (A.F.); +20-102-3884804 (S.E.-D.H.)

Abstract: The discovery of eco-friendly, rapid, and cost-effective compounds to control diseases caused by microbes and insects are the main challenges. Herein, the magnesium oxide nanoparticles (MgO-NPs) are successfully fabricated by harnessing the metabolites secreted by Penicillium chrysogenum. The fabricated MgO-NPs were characterized using UV-Vis, XRD, TEM, DLS, EDX, FT-IR, and XPS analyses. Data showed the successful formation of crystallographic, spherical, well-dispersed $\mathrm{MgO}-\mathrm{NPs}$ with sizes of 7-40 nm at a maximum wavelength of $250 \mathrm{~nm}$. The EDX analysis confirms the presence of $\mathrm{Mg}$ and $\mathrm{O}$ ions as the main components with weight percentages of $13.62 \%$ and $7.76 \%$, respectively. The activity of $\mathrm{MgO}-\mathrm{NPs}$ as an antimicrobial agent was investigated against pathogens Staphylococcus aureus, Bacillus subtilis, Pseudomonas aeruginosa, Escherichia coli, and Candida albicans, and exhibited zone of inhibitions of $12.0 \pm 0.0,12.7 \pm 0.9,23.3 \pm 0.8,17.7 \pm 1.6$, and $14.7 \pm 0.6 \mathrm{~mm}$ respectively, at $200 \mu \mathrm{g} \mathrm{mL}^{-1}$. The activity is decreased by decreasing the MgO-NPs concentration. The biogenic MgO-NPs exhibit high efficacy against different larvae instar and pupa of Anopheles stephensi, with LC50 values of 12.5-15.5 ppm for I-IV larvae instar and 16.5 ppm for the pupa. Additionally, $5 \mathrm{mg} / \mathrm{cm}^{2}$ of MgO-NPs showed the highest protection percentages against adults of Anopheles stephensi, with values of $100 \%$ for $150 \mathrm{~min}$ and $67.6 \% \pm 1.4 \%$ for $210 \mathrm{~min}$.

Keywords: green synthesis; MgO-NPs; pathogenic microbes; Anopheles stephensi; biocontrol; mosquitocidal

\section{Introduction}

Nanotechnology is a multidisciplinary science, highly developed during the last two decades to improve and solve a lot of challenges and problems in various fields, such as medicine, environment, agriculture, food, and different industries [1,2]. The new nano-sized materials (1-100 nm) are synthesized based on three basic approaches, including chemical, physical, and biological processes [3]. The synthesized process can be accomplished by two techniques, bottom-up and top-down. The aggregation of atoms to atoms to form new nanomaterials is defined as self-aggregation or bottom-up, whereas the breakdown of starting bulk materials to small or nano-sized is known as the top-down technique $[4,5]$. 
The chemical and physical fabrication processes frequently require distinct processing materials and harsh conditions, including unsafe chemicals, pressure, optimized $\mathrm{pH}$, controlled temperature, and expansive instruments. Finally, these fabrication processes are high cost and generate undesirable by-products that cause several diverse ecosystems' problems [4]. On the contrary, the biological route is characterized by being a simple, rapid, eco-friendly, and low-cost method, as compared to chemical and physical processes [6]. Therefore, researchers' attention is directed to the green method or biological method using bacteria, fungi, actinomycetes, algae, yeast, and plants to fabricate nanomaterials [7-11]. Recently, there is a huge number of nanomaterials being fabricated using biological methods, such as $\mathrm{Ag}, \mathrm{Au}, \mathrm{Cu}, \mathrm{CuO}, \mathrm{ZnO}, \mathrm{Fe}_{2} \mathrm{O}_{3}, \mathrm{TiO}_{2}$, and others [12-17].

Fungi are considered one of the most biological entities used for the biological synthesis of NPs due to their ability to secrete varied metabolites such as proteins and enzymes which are used for reducing, capping, and stabilizing nanomaterials [18]. Moreover, due to scalability, high efficacy to metal tolerance, easy handling, high biomass production, and economic livability, all these properties give fungi priority to be used as a template for fabricating various nanoparticles [5]. Penicillium chrysogenum is the most common fungal species that produces a wide range of metabolites, for instance, fungisporin, roquefortines, penitric acid, siderophores, indole-3-acetic acid, varied enzymes, chrysogenin, $\omega$-hydroxyemodin, and chrysogine [19-21]. Therefore, it can be used as a platform to produce different metal and metal oxide nanoparticles.

The metal oxide nanoparticles have extra advantages such as high chemical stability and less toxicity as compared with other metal nanoparticles [22]. These extra advantages give metal oxides the priority to incorporate into various biomedical and biotechnological applications [23]. Among metal oxide nanoparticles, magnesium oxide nanoparticles (MgNPs) have a unique set of desired applications because they possess unique properties, such as photocatalytic characteristics, higher ionic, less toxic to human and animal tissues, and are more stabilized in the body fluids [24]. The MgO-NPs can be integrated into various applications, such as biocatalysts, superconductors, paints, optical imaging, antiadhesion, and wastewater treatment $[25,26]$. Moreover, they can be used for numerous biological purposes, such as antibiofilm, antifungal, antibacterial, antiviral, antitumor, anticancer, biosensors, heartburn treatments, molecular signaling, bone regeneration, to lower the complications of magnesium shortage, and as additives to killing food-borne pathogens [27-29]. $\mathrm{MgO}-\mathrm{NPs}$ are characterized by low volatility and tolerate high-temperatures, so they can be used as an antimicrobial agent with long-term effects, and interestingly, are proven as a safe nano-compound by the FDA [30,31].

The current study focuses on investigating the multifunctional properties of $\mathrm{MgO}-$ NPs fabricated through harnessing metabolites of Penicillium chrysogenum. The physicochemical characterizations of biosynthesized MgO-NPs were accomplished using UV-Vis spectroscopy, XRD, TEM, DLS, SEM-EDX, FTIR, and XPS analyses. Moreover, the biological activities of biosynthesized MgO-NPs summarized on antimicrobial activity against pathogenic Gram-positive and Gram-negative bacteria, and unicellular fungi, were investigated. Also, the larvicidal, pupicidal, and repellent activity toward Anopheles stephensi malarial vector were assessed.

\section{Results and Discussion}

\subsection{Isolation and Identification of the Fungal Isolate}

The current study adopts an eco-friendly, cost-effective, and biocompatibility approach to the green synthesis of one important metal oxide, magnesium oxide nanoparticles (MgO$\mathrm{NPs}$ ). The fungal isolate A2 was isolated from the soil sample and selected for green synthesis of MgO-NPs based on their rapid and greater synthesis. This isolate underwent cultural, microscopic, and molecular identification based on sequence and amplification of the ITS gene. The primary identification based on cultural characteristics showed that the diameter of colonies on malt extract agar media was ranging between 25 and $40 \mathrm{~mm}$, moderate to heavy conidial production, the observed color is dull green, and the 
reverse color is pale yellow or yellowish-brown (Figure 1A,B). On the other hand, the microscopic examination showed that the conidiophores are usually borne from the surface or subsurface hyphae, and stipes are smooth thin walls of approximately 200 to $300 \mu \mathrm{m}$ long. The penicilli are 1-2 rami, terverticillate, and usually terminal or subterminal. Phialides appeared with a long diameter of 7-8 $\mu \mathrm{m}$, while the conidia appeared as a smooth wall of 2.5-4.0 $\mu \mathrm{m}$ long and borne in highly irregular columns (Figure 1C). Based on cultural and microscopic examination, isolate A2 belongs to Penicillium spp. [20,32].

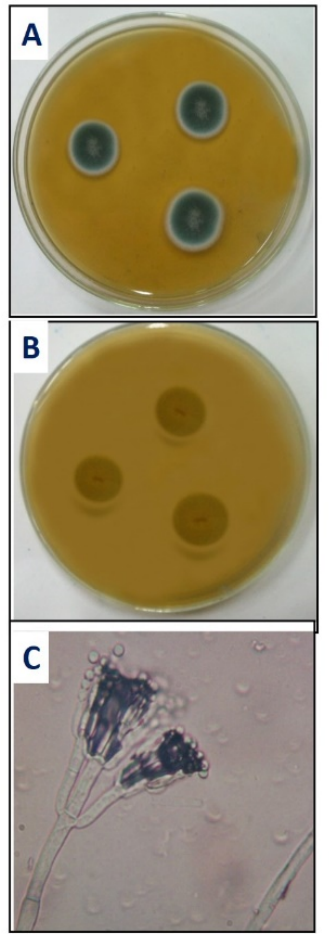

D

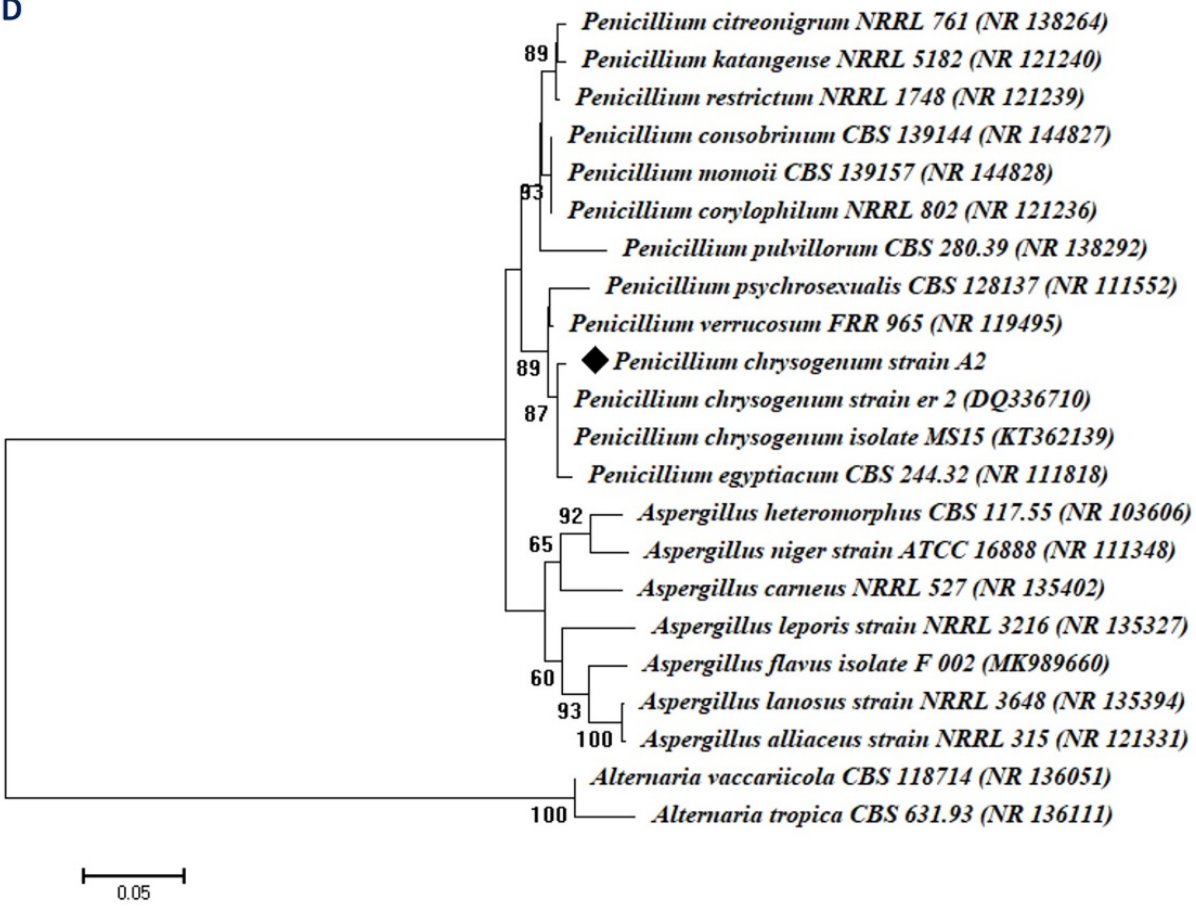

Figure 1. Cultural, microscopic, and ITS sequence analysis of fungal isolate A2. (A) Colony of fungal isolate A2 on malt extract agar media, (B) reverse colony of isolate A2 on malt extract agar media, (C) bright-field microscopic examination $(\mathrm{X}=800)$, and $(\mathrm{D})$ phylogenetic tree of isolate A2 with the sequences from NCBI. The symbol refers to ITS fragments retrieved from this study. The tree was conducted with MEGA 6.1 using the neighbor-joining method.

Moreover, the sequence analysis of fungal isolate A2 was highly similar to Penicillium chrysogenum (accession number: NR077145) with percentages of $97.1 \%$. Hence, the fungal isolate A2 used in the current study was identified as Penicillium chrysogenum strain A2 (Figure 1D). The sequence obtained in this study was deposited in Gene Bank under accession number MW774585.

Recently, Penicillium chrysogenum strains have been used as a biocatalyst for the green synthesis of a wide range of metal and metal oxide NPs [33,34]. These activities could be attributed to the efficacy of $P$. chrysogenum to produce novel active metabolites which are utilized for reducing, capping, and stabilizing metal and metal oxide NPs [35,36]. To date, this is the first report for the green synthesis of MgO-NPs fabricated by P. chrysogenum.

\subsection{Green Synthesis of $\mathrm{MgO}-\mathrm{NPs}$}

Fungi are considered a promising tool for the green synthesis of metal and metal oxide NPs due to their reservoir for bioactive compounds. Fungi also tolerate and accumulate a high concentration of metals, and they are characterized by easy handling, biocompatibility, and scalability $[5,35]$. In the current study, cell filtrate of P. chrysogenum A2 participated in the green synthesis of MgO-NPs through reducing $\mathrm{Mg}^{2+}$ present in the precursor $(\mathrm{Mg}$ $\left.\left(\mathrm{NO}_{3}\right)_{2} \cdot 6 \mathrm{H}_{2} \mathrm{O}\right)$ by electrons liberated during the reduction of $\mathrm{NO}_{3}$ to $\mathrm{NO}_{2}$ [37]. 
At first, the fungal cell-free extract reduced the precursor to form a turbid white precipitate of $\mathrm{Mg}(\mathrm{OH})_{2}$, which was collected and rinsed with distilled water to remove any impurities.

$$
\mathrm{Mg}\left(\mathrm{NO}_{3}\right)_{2} \cdot 6 \mathrm{H}_{2} \mathrm{O}+\mathrm{H}_{2} \mathrm{O} \underset{\text { Metabolites }}{\stackrel{\text { Fungal }}{\longrightarrow}} \mathrm{Mg}(\mathrm{OH})_{2}
$$

After that, the as-formed $\mathrm{Mg}(\mathrm{OH})_{2}$ was calcinated at $400{ }^{\circ} \mathrm{C}$ for $4 \mathrm{~h}$ to form MgO-NPs, as reported by Essien et al. [38]:

$$
\mathrm{Mg}(\mathrm{OH})_{2} \stackrel{400{ }^{\circ} \mathrm{C}}{\rightarrow} \mathrm{MgO}-\mathrm{NPs}
$$

\subsection{Characterizations of Biosynthesized MgO-NPs}

\subsubsection{UV-Vis Spectroscopy Analysis}

The color intensity as an indicator for MgO-NPs synthesis was monitored by detecting the maximum surface plasmon resonance (SPR) using UV-Vis spectroscopy. Data analysis showed that the maximum SPR for MgO-NPs synthesized by P. chrysogenum A2 was $250 \mathrm{~nm}$ (Figure 2A). The morphological characteristics of NPs such as size, shape, and distributions are usually correlated with their SPR, as reported previously [39]. Moreover, the size of MgO-NPs was small or large according to the SPR values of less or more than $300 \mathrm{~nm}$, respectively [40]. Interestingly, the SPR of MgO-NPs synthesized by Rosmarinus officinalis L. was observed at $250 \mathrm{~nm}$ [41]. Also, Essien et al. [38] showed that the SPR of MgO-NPs fabricated by Manihot esculenta was $260 \mathrm{~nm}$. Based on obtained data, it can be concluded that metabolites secreted by P. chrysogenum A2 were efficient to fabricate $\mathrm{MgO}$ at the nanoscale.
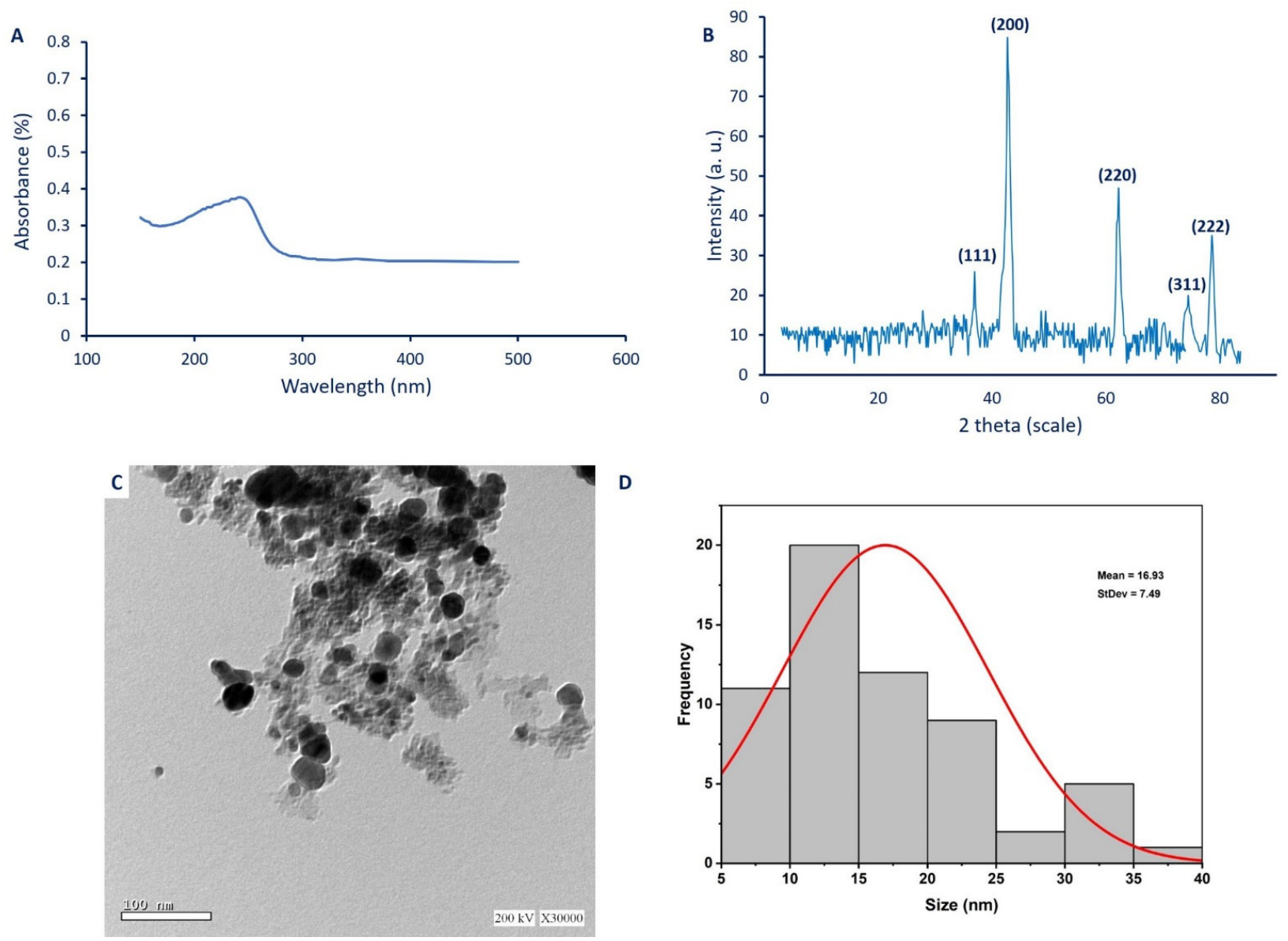

Figure 2. Characterization of biosynthesized MgO-NPs. (A) UV-Vis spectroscopy showed maximum SPR at $250 \mathrm{~nm}$, (B) XRD analysis showed crystalline nature of biosynthesized MgO-NPs, (C) TEM image, and (D) size distribution of MgO-NPs. 


\subsubsection{X-Ray Diffraction (XRD)}

The XRD analysis is used to detect or measure the crystalline nature of green synthesized MgO-NPs. The XRD pattern showed five sharp peaks at $2 \theta^{\circ}$ of $36.8^{\circ}, 42.7^{\circ}, 62.1^{\circ}$, $46.4^{\circ}$, and $78.5^{\circ}$, which indexed to (111), (200), (220), (311), and (222) planes (Figure 2B). The presence of some little peaks indicates that the sample has some impurities [41]. The observed peaks confirm the successful formation of the crystallographic phase of facecentered-cubic (FCC) structure according to JCPDS file No. (89-7746) [42]. The XRD pattern confirms the presence of $\mathrm{Mg}(\mathrm{OH})_{2}$ and $\mathrm{MgO}$ in the sample, and this finding is confirmed by XPS analysis. The observed plan peaks of (111) and (311) at $2 \theta^{\circ}$ values of $36.8^{\circ}$ and $46.4^{\circ}$ refer to $\mathrm{Mg}(\mathrm{OH})_{2}$, whereas plan peaks of (200), (220), and (222) refer to $\mathrm{MgO}$ [43]. In most cases, the final product contains $\mathrm{Mg}(\mathrm{OH})_{2}$ and $\mathrm{MgO}$, and can eliminate the $\mathrm{Mg}(\mathrm{OH})_{2}$ by elevating the temperature to $700{ }^{\circ} \mathrm{C}$ as previously reported [44]. The crystal size of NPs can be calculated from the XRD pattern using the Debye-Scherrer equation. Data showed that the average crystal size of MgO-NPs was $48 \mathrm{~nm}$. Recently, the particle size of MgO-NPs synthesized by harnessing metabolites of Aspergillus carbonarious D-1 calculated using the Debye-Scherrer equation was $35 \mathrm{~nm}$ [45], whereas those synthesized by leaf extract of Azadirachta indica was $27 \mathrm{~nm}$ [46].

\subsubsection{Transmission Electron Microscopy (TEM)}

TEM analysis is a useful technique to investigate the morphological characteristics of NPs, such as shape, size, and agglomeration percentages [47]. In this study, the TEM image showed the efficacy of metabolites secreted by P. chrysogenum to fabricate spherical $\mathrm{MgO}$ with a size range of 7-40 nm, with an average diameter of $16.9 \pm 7.5 \mathrm{~nm}$ (Figure 2C,D). The TEM image exhibits the well-dispersed green synthesized MgO-NPs without any aggregation. The obtained data are consistent with Bindhu et al. [48], who successfully synthesized well-dispersed, spherical MgO-NPs, with a size range of 7-38 nm and an average size of $16 \mathrm{~nm}$. The biological activities of NPs are known to correlate with their size, and if the size is decreased, the activities are increased [5]. For example, MgO-NPs with varied sizes of 35.9, 47.3, and $2145.9 \mathrm{~nm}$ showed different potential to inhibit the growth of Bacillus subtilis, with percentages of $96.1 \%, 94.5 \%$, and $75.7 \%$, respectively [49]. Therefore, based on the obtained size of green synthesized MgO-NPs in the current study, we predict that the activities are high.

\subsubsection{Dynamic Light Scattering (DLS) Analysis}

The nanoparticles' size, as well as the size distribution of biosynthesized MgO-NPs, were analyzed using the DLS technique based on hydrodynamic diameters. The histogram of the particle size distribution (Figure $3 \mathrm{~A}$ ) showed that the average hydrodynamic particle diameters were 55.8 and $20.13 \mathrm{~nm}$ for volume intensity of $2.3 \%$ and $97.7 \%$. The average size obtained by the DLS technique is bigger than those recorded by TEM and XRD because of coating metabolites on the NPs surface, which are used for capping and stabilizing MgO-NPs [50,51]. Additionally, the high diameter size of NPs measured by DLS could be attributed to the non-homogeneous distribution of particles in the colloidal solution $[52,53]$.

The DLS analysis provides more information about the homogeneity of particles into the colloidal solution by measuring the polydispersity value (PDI) [4]. The homogeneity was increased or decreased according to the PDI value, where it increased if the PDI value is less than 0.4 and decreased if the PDI value is more than 0.4 , as reported previously [54]. If the PDI value is more than 1.0, the solution becomes highly heterogeneous. In the current study, the PDI value of biosynthesized MgO-NPs was 0.3 , which indicates the homogeneity of MgO-NPs colloidal solution. 

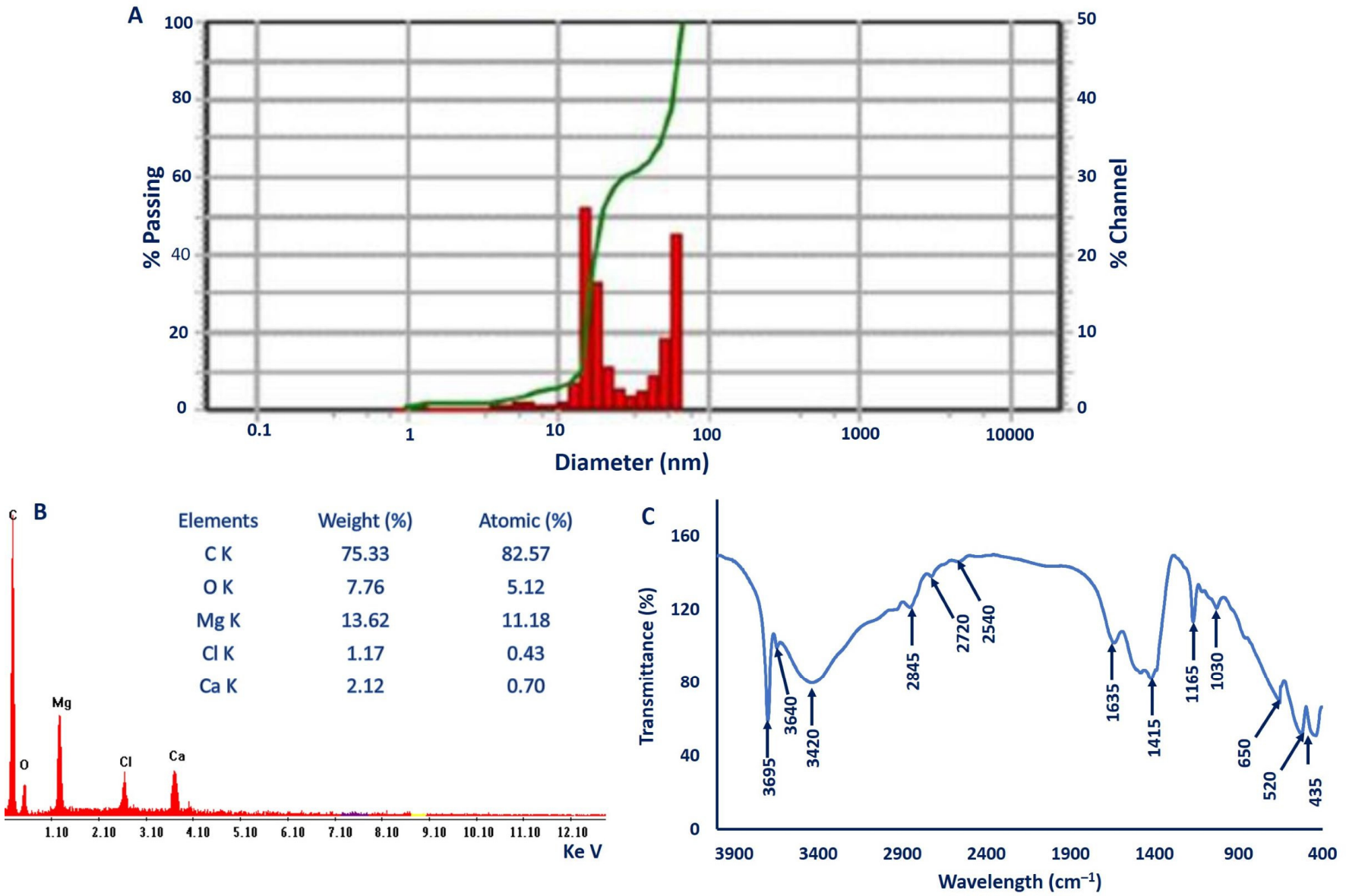

Figure 3. Characterization of biosynthesized MgO-NPs. (A) Dynamic light scattering (DLS) analysis, (B) energy dispersive X-ray (EDX) analysis, and (C) Fourier transform infrared (FT-IR) spectroscopy.

\subsubsection{Energy Dispersive X-ray (EDX) Analysis}

The qualitative and quantitative compositions of as-formed MgO-NPs were analyzed using EDX analysis. The EDX graph demonstrated the presence of $\mathrm{Mg}$ and $\mathrm{O}$ elements in the sample, which confirms the successful fabrication of $\mathrm{MgO}$ by metabolites secreted by $P$. chrysogenum. The presence of $\mathrm{Mg}$ and $\mathrm{O}$ peaks at bending energy between 0.5 and $1.5 \mathrm{KeV}$ indicate the successful formation of $\mathrm{MgO}$ [55]. The quantitative analysis confirms the presence of $\mathrm{Mg}$ and $\mathrm{O}$ with weight percentages of $13.62 \%$ and $7.76 \%$ respectively, while the atomic percentages of $\mathrm{Mg}$ and $\mathrm{O}$ ions in the sample were $11.18 \%$ and $5.12 \%$, respectively (Figure 3B). The presence of other peaks in EDX spectra indicates the presence of some impurities in the sample, which is confirmed by XRD and XPS analyses. The weight percentages of $\mathrm{C}, \mathrm{Cl}$, and $\mathrm{Ca}$ ions were $75.33 \%, 1.17 \%$, and $2.12 \%$, respectively. Consistent with our study, Dobrucka [55] reported the presence of additional peaks, including $\mathrm{Al}, \mathrm{Si}$, $\mathrm{K}$, and $\mathrm{Ca}$, besides $\mathrm{Mg}$ and $\mathrm{O}$ during phytosynthesis of MgO-NPs by Artemisia abrotanum. These additional peaks could be attributed to the breakdown of metabolites around the biosynthesized MgO-NPs by X-ray emission [56,57].

\subsubsection{Fourier Transform Infrared (FT-IR) Spectroscopy}

The roles of functional groups present in fungal biomass filtrate in reducing and forming of MgO-NPs were analyzed using FT-IR, which was measured at wavenumbers of $400-4000 \mathrm{~cm}^{-1}$ (Figure 3C). The sharp peak at $3695 \mathrm{~cm}^{-1}$ was assigned to the $\mathrm{OH}$ stretching band [58], while the broadband observed at $3420 \mathrm{~cm}^{-1}$ was assigned to the $\mathrm{O}-\mathrm{H}$ stretching of hydroxyls overlapped with $\mathrm{N}-\mathrm{H}$ stretching vibration of amines found in the polysaccharide $[55,59]$. A series of low resolved peaks that appeared in the range 
$2900-2700 \mathrm{~cm}^{-1}$ (overlapped with the broadness peak of $\mathrm{N}-\mathrm{H}$ and O-H stretching band) were assigned to $\mathrm{C}-\mathrm{H}$ stretching of aliphatic hydrocarbons with methoxy $\mathrm{CH}_{3}$-O- (i.e., $2845 \mathrm{~cm}^{-1}$ ) [60], and also, the band that appeared at $2720 \mathrm{~cm}^{-1}$ was mainly assigned to methylamine $\mathrm{N}-\mathrm{CH}_{3}$ and $\mathrm{C}-\mathrm{H}$ stretching [60]. These results were identical with the data obtained from the XPS analysis for $\mathrm{C} 1 \mathrm{~s}, \mathrm{O} 1 \mathrm{~s}$, and $\mathrm{N} 1 \mathrm{~s}$ binding energies.

A high resolved peak with broadness that appeared at $1635 \mathrm{~cm}^{-1}$ was assigned to $\mathrm{C}=\mathrm{O}$ of amide, carboxylate (carboxylic acid salt), and $\mathrm{N}-\mathrm{H}$ stretching vibration, while the other peak at $1415 \mathrm{~cm}^{-1}$ related to bending of $\mathrm{C}-\mathrm{H}$ bonds, and $\mathrm{C}=\mathrm{O}$ of carboxylate [61]. The peak at $1165 \mathrm{~cm}^{-1}$ was assigned to the $\mathrm{C}-\mathrm{O}$ stretch of the alcohol that was present in the hydrocarbon skeletons, which overlapped with C-N stretching of tertiary amine (see the XPS analysis) [60]. The low resolved peak at $1030 \mathrm{~cm}^{-1}$ was related to C-H out-of-plane bend, $\mathrm{C}-\mathrm{O}$ stretching, $\mathrm{CN}$ stretch of primary amine [60,62], and $\mathrm{Mg}-\mathrm{OH}$ stretching [63]. Peaks were found at 650 and $520 \mathrm{~cm}^{-1}$ in the figure print region, identical to the $\beta$-Dglucose unit (from the hydrocarbons), bending of free amine bond [62,64], as well as $\mathrm{Mg}-\mathrm{O}$ vibration peaks, which verify the successful fabrication of these particles $[58,65]$. Based on FT-IR analysis, the presence of different functional groups for polysaccharides, hydrocarbons, amines, carboxylate, and amino groups confirms the efficacy of metabolites involved in fungal biomass filtrate for reducing, capping, and stabilizing MgO-NPs.

\subsubsection{X-ray Photoelectron Spectroscopy (XPS) Analysis}

The characterization of the MgO NP was completed by the analysis of XPS. Figure 4A shows the overall survey spectra which studied the selected binding energy ranges. This survey showed binding energies of $\mathrm{C} 1 \mathrm{~s}, \mathrm{O}$ (1s 2s, KL1, and KL2), N 1s, and $\mathrm{Cl}(1 \mathrm{~s}, 2 \mathrm{p})$, while different species of Mg were detected (i.e., 2s, 2p, KL1, KL2, KL3, KL4, KL5, and 1s), indicating the majority of this component over others.

The chemical compositions are clearly shown when comparing the different profiles of the signals as well as their deconvolutions. The $\mathrm{C} 1$ s spectra (Figure 4B) shows five splitting peaks for $\mathrm{C}(\mathrm{C}, \mathrm{N}, \mathrm{H}), \mathrm{C}(=\mathrm{N}, \mathrm{O})$, or $\mathrm{C}-\mathrm{O}-\mathrm{C}, \mathrm{N}-\mathrm{C}=\mathrm{O}$ (amide), $\mathrm{O}-\mathrm{C}=\mathrm{O}$, and $\mathrm{O}-\mathrm{C}-\mathrm{O}$ at 284.07, $285.48,287.31$, and $289.89 \mathrm{eV}$ respectively $[62,66,67]$, and this gives good evidence for the carbohydrate produced by the organisms. The $\mathrm{O} 1 \mathrm{~s}$ spectra (Figure $4 \mathrm{C}$ ) shows two internal splitting peaks at 530.82 and $532.27 \mathrm{eV}$, which are assigned for $\mathrm{O}(\mathrm{N}, \mathrm{C}, \mathrm{H}), \mathrm{O}-\mathrm{C}=\mathrm{O}[68,69]$, and this supports the data produced by the $C 1$ s deconvolutions. The $N$ 1s (Figure $4 \mathrm{D}$ ) was deconvoluted into five internal peaks at $398.87 \mathrm{eV}$ for $\mathrm{N}(\mathrm{C}, \mathrm{H})$ and $400.34 \mathrm{eV}$ for $\mathrm{N}_{\text {tert }}$ of polysaccharides [70], while the medium reflects three peaks for $\mathrm{NO}, \mathrm{NO}_{2}$, and $\mathrm{NO}_{3}$ at 402.8, 405.77 , and $406.68 \mathrm{eV}$ respectively, resulted from the source of nitrate used for dissolving the salt [71].

The XPS spectra of $\mathrm{Mg}$ shows predominately $\mathrm{MgO}$ over $\mathrm{Mg}(\mathrm{OH})_{2}$, and these were shown by the deconvolution of $\mathrm{Mg}$ 1s, which produced two peaks at $1304.44 \mathrm{eV}$ (major) for $\mathrm{MgO}$ with At. 94.74\%, and the other peak (5.26 At\%; minor) at $1306.28 \mathrm{eV}$ [72]. The $\mathrm{Mg}$ 2p also shows two peaks for $\mathrm{MgO}$ and $\mathrm{Mg}-\mathrm{OH}$ at 49.49 and $48.74 \mathrm{eV}$, with At. $95.89 \%$ and $4.11 \%$, respectively [73,74]. Again, progressively more increased $\mathrm{MgO}$ than $\mathrm{Mg}(\mathrm{OH})_{2}$ was shown in the $\mathrm{Mg}$ 2s spectra, which deconvoluted into two peaks at $88.24 \mathrm{eV}$ (At. 91.77\%) and $87.61 \mathrm{eV}$ (At. $8.23 \%$ ) for $\mathrm{MgO}$ and $\mathrm{Mg}(\mathrm{OH})_{2}$, respectively [74]. From this data, it was clear that $\mathrm{MgO}$ is the main species in composite materials.

\subsection{Antimicrobial Activity}

The use of various antibiotics has led to the spread of microbial resistance; therefore, it is necessary to discover new compounds that have antimicrobial activity. Biosynthesized MgO-NPs have unique properties, making them a good source to develop new antimicrobial compounds [75]. In the current study, the potentiality of biosynthesized $\mathrm{MgO}-\mathrm{NPs}$ to inhibit the pathogenic Gram-positive and Gram-negative bacteria, and unicellular fungi, was investigated using the agar well diffusion method. Data analysis showed that the activities of biosynthesized MgO-NPs as antibacterial and anti-candida were dosedependent, where the activities increased by increasing the NPs concentrations. These 
findings were compatible with published studies about nanomaterials as antimicrobial agents $[15,76,77]$. The zones of inhibition (ZOI) formed due to the highest MgO-NPs concentration $\left(200 \mu \mathrm{g} \mathrm{mL}^{-1}\right)$ were $12.7 \pm 0.9,12.0 \pm 0.0,23.3 \pm 0.8,17.7 \pm 1.6$, and $14.7 \pm 0.6 \mathrm{~mm}$ for Bacillus subtilis, Staphylococcus aureus, Pseudomonas aeruginosa, Escherichia coli, and Candida albicans, respectively (Figure 5). Umaralikhan and Jaffar [78] reported that the ZOI formed due to treatment with $5 \mathrm{mg} \mathrm{mL}^{-1}$ of MgO-NPs synthesized by Pisidium guvajava was 16 and $15 \mathrm{~mm}$ for $S$. aureus and E. coli respectively, while those synthesized by Aloe vera formed ZOI with the value of 15 and $12 \mathrm{~mm}$ against the same organisms.
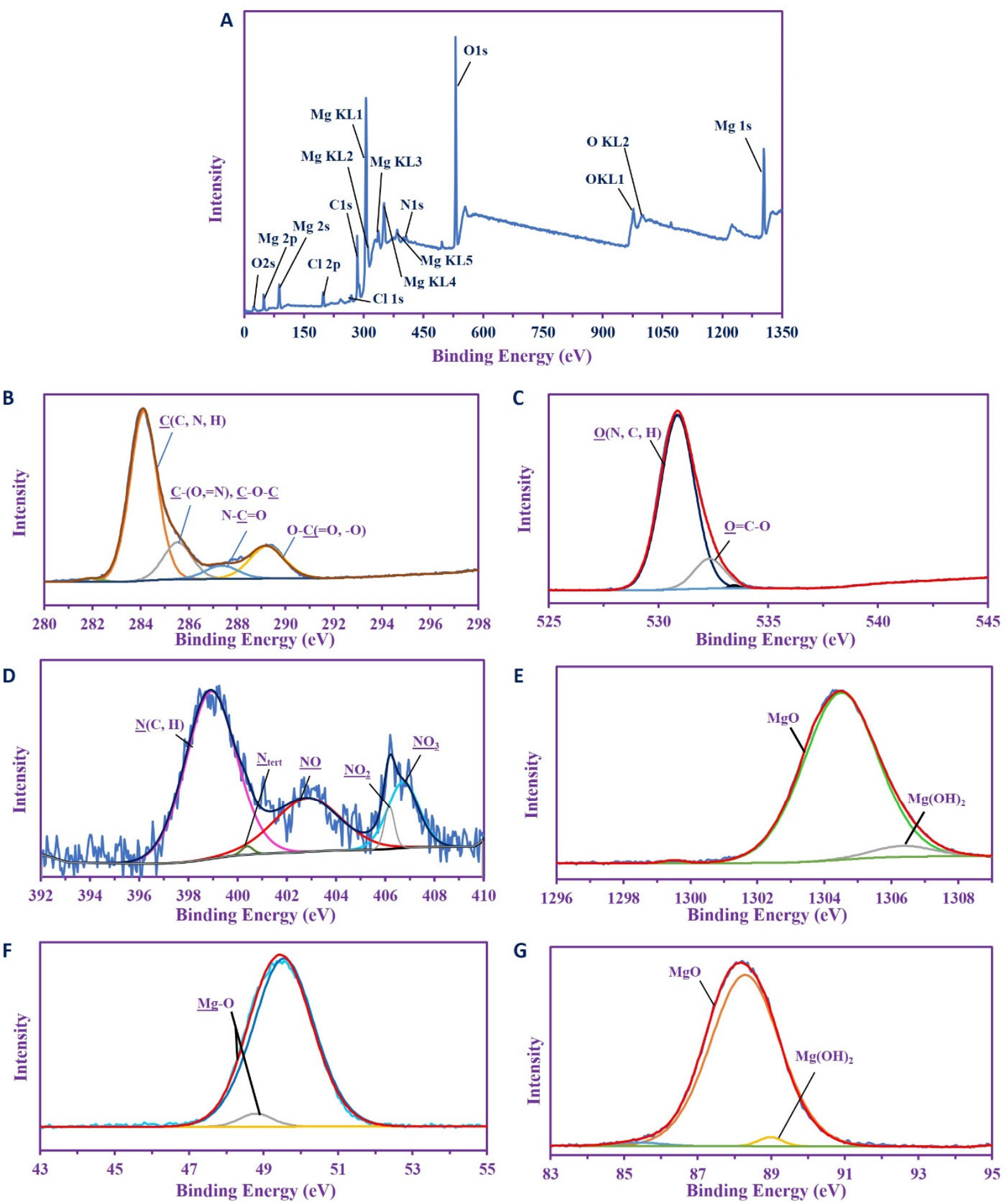

Figure 4. XPS analysis of biosynthesized MgO-NPs. (A) Overall survey, (B) C 1s, (C) O 1s, (D) N 1s, (E-G) Mg 1s, Mg 2p, and $\mathrm{Mg}$ 2s, respectively. 


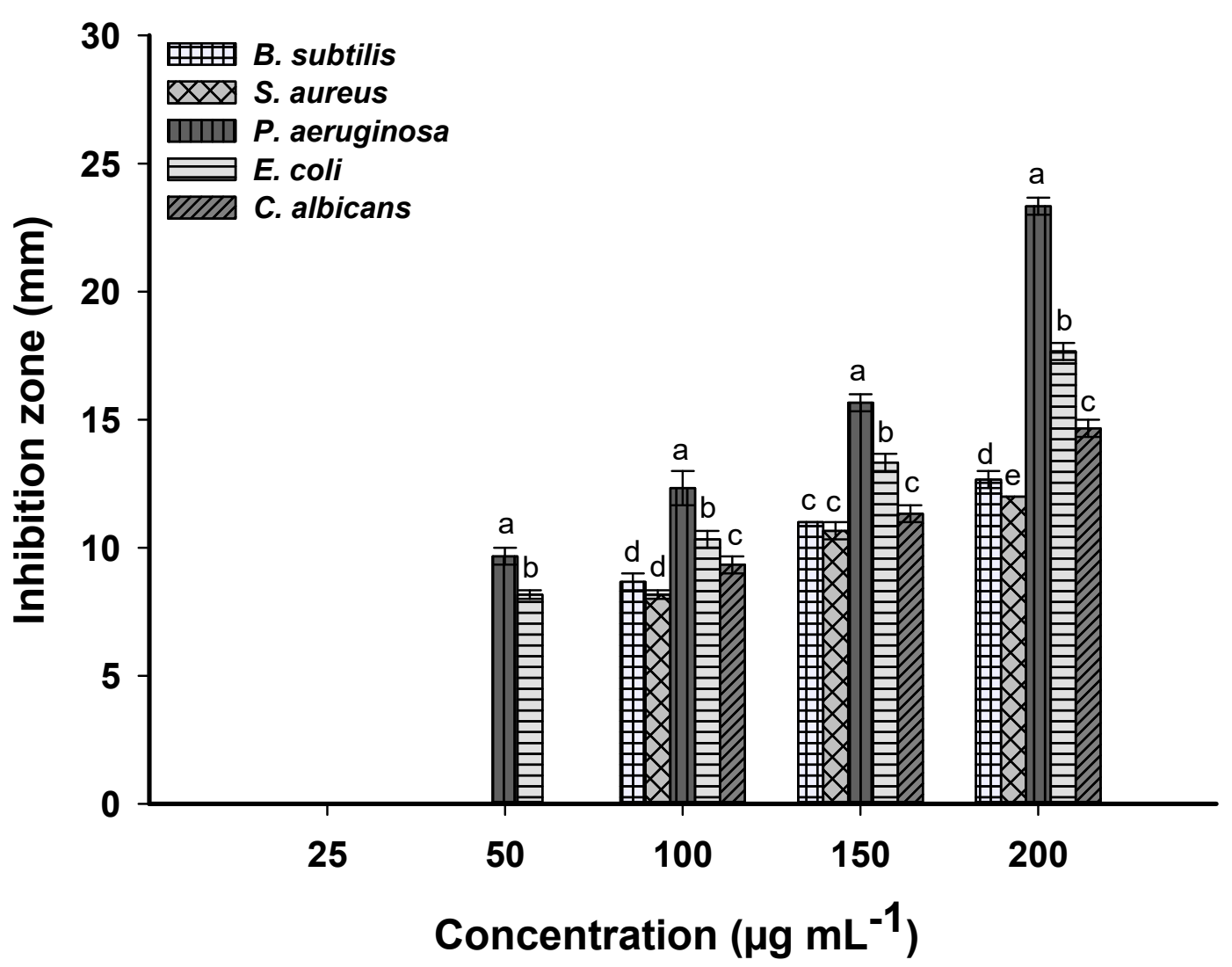

Figure 5. Antimicrobial activity of biosynthesized MgO-NPs against pathogenic Gram-positive and Gram-negative bacteria, and unicellular fungi. Different letters $(a, b, c, d$ and e) on bars at the same concertation denote that mean values are significantly different $(p \leq 0.05)(n=3)$.

The MIC values, which are defined as the minimum $\mathrm{MgO}$ concentration that can inhibit the microbial growth, were assessed through examination of various concentrations (100, 50, $25 \mu \mathrm{g} \mathrm{mL}^{-1}$ ). Data showed that the MIC value for B. subtilis, S. aureus, and C. albicans was $100 \mu \mathrm{g} \mathrm{mL}{ }^{-1}$, with ZOIs of $8.7 \pm 0.6,8.2 \pm 0.3$, and $9.3 \pm 0.9 \mathrm{~mm}$, respectively. Whereas the MIC value for Gram-negative bacteria, P. aeruginosa, and E. coli was $50 \mu \mathrm{g} \mathrm{mL}{ }^{-1}$, with ZOIs of $9.7 \pm 0.5$ and $8.2 \pm 0.3 \mathrm{~mm}$, respectively.

Based on obtained data, the Gram-negative bacteria are more sensitive to biosynthesized MgO-NPs than Gram-positive bacteria. This activity can be attributed to the difference in the cell wall structure between the two kinds. The cell wall of Gram-positive bacteria contains a thick layer of peptidoglycans, in contrast to Gram-negative bacteria, which contain a thin layer of peptidoglycans and extra lipopolysaccharides (LIP). The attraction between NPs and bacterial cell wall was due to the negative charge on the LIP and positive charge on the NPs surface [79]. Additionally, because of the small size of biosynthesized MgO-NPs, which in the current study was $16.9 \pm 7.5 \mathrm{~nm}$, they can penetrate the thin peptidoglycan layer easily and hence disrupt the selective permeability functions of the microbial cell membrane [80]. Moreover, the entrance of MgO-NPs into the microbial cell led to blocking the quorum sensing between cells and hence, inhibited the cellular functions [81].

Besides the previous mechanism, some authors regard the antimicrobial activity of MgO-NPs to the production of reactive oxygen species (ROS), dissociation of $\mathrm{Mg}^{2+}$ ions inside the microbial cells, and alkaline effects. The ROS enhances the formation of hydrogen peroxide $\left(\mathrm{H}_{2} \mathrm{O}_{2}\right)$, superoxide radicals $\left({ }^{-} \mathrm{O}_{2}\right)$, and reactive hydroxyl radical $\left({ }^{\bullet} \mathrm{OH}\right)$, which react with nucleic acids and proteins and hence destroy the internal cellular 
components [63]. The dissociated $\mathrm{Mg}^{2+}$ ion inside the cells reacts with the -SH group of amino acids and leads to the breakdown of protein structure, and ultimately to cell death [65]. Finally, the water vapor condenses on the MgO-NPs surface, forming a thin water zone characterized by a greater $\mathrm{pH}$ value than the equilibrium state. Once $\mathrm{MgO}-\mathrm{NPs}$ react with microbial cells, the greater $\mathrm{pH}$ in the formed water zone leads to destroying the cell wall and cell membranes, ending in cell death [82].

\subsection{Larvicidal/Pupicidal Bioassay}

Mosquitoes are considered the main carriers of pathogens in most equatorial and subtropical countries. Mosquitoes are the causative agent for malaria, dengue fever, yellow fever, filariasis, chikungunya, encephalitis, and others [83]. The most common insecticides used are synthetic compounds that disrupt a biological system due to repeated and uncontrollable usage. Therefore, it is urgent to discover new eco-friendly active compounds that have mosquitocidal properties. Herein, the efficacy of biosynthesized MgO-NPs as larvicidal for Anopheles stephensi was investigated. Data analysis showed that the potentiality of $\mathrm{MgO}-\mathrm{NPs}$ as larvicidal and pupicidal was dose- and time-dependent. Data represented in Table 1 show that the percentages of larvae mortality increased from $30.2 \% \pm 1.09 \%$ (I instar), $29.6 \% \pm 1.14 \%$ (II instar), $27.8 \% \pm 1.30 \%$ (III instar), and $24.4 \% \pm 1.94 \%$ (IV instar) at $5 \mathrm{ppm}$ to $91.8 \% \pm 2.38 \%$ (I instar), $88.2 \% \pm 1.64 \%$ (II instar), $81.4 \% \pm 0.89 \%$ (III instar), and $72.8 \% \pm 2.58 \%$ (IV instar) at $25 \mathrm{ppm}$. Moreover, the LC50 (the concentration of $\mathrm{MgO}-\mathrm{NPs}$ that causes $50 \%$ mortality) increased from $12.4 \mathrm{ppm}$ for I instar to $15.6 \mathrm{ppm}$ for IV instar, while LC90 (the concentration of MgO-NPs that causes $90 \%$ mortality) increased from $22.3 \mathrm{ppm}$ for I instar to reach $27.9 \mathrm{ppm}$ for IV instar. On the other hand, the mortality percentages of pupa due to treatment with the highest MgO-NPs concentration (25 ppm) was $69.2 \% \pm 2.8 \%$, with LC50 of $16.5 \mathrm{ppm}$ and LC90 of $29.8 \mathrm{ppm}$.

Table 1. The toxicity of biosynthesized MgO-NPs against $A$. stephensi larvae and pupa.

\begin{tabular}{|c|c|c|c|c|c|c|c|}
\hline \multirow{2}{*}{ Target Instar } & \multicolumn{5}{|c|}{ Mortality Percentages (\%) \pm SD * } & \multirow{2}{*}{ LC50 } & \multirow{2}{*}{ LC90 } \\
\hline & $5 \mathrm{ppm}$ & 10 ppm & 15 ppm & 20 ppm & $25 \mathrm{ppm}$ & & \\
\hline $\mathrm{I}$ & $30.2 \pm 1.1$ & $48.6 \pm 1.7$ & $67.6 \pm 2.5$ & $79.2 \pm 2.2$ & $91.8 \pm 2.4$ & 12.4 & 22.3 \\
\hline II & $29.6 \pm 1.1$ & $41.8 \pm 1.1$ & $64.2 \pm 1.9$ & $75.6 \pm 1.1$ & $88.2 \pm 1.6$ & 13.10 & 23.5 \\
\hline III & $27.8 \pm 1.3$ & $41.4 \pm 1.8$ & $59.8 \pm 2.9$ & $72.4 \pm 2.9$ & $81.4 \pm 0.9$ & 13.93 & 25.09 \\
\hline IV & $24.4 \pm 1.9$ & $35.6 \pm 2.3$ & $51.4 \pm 1.5$ & $67.6 \pm 2.6$ & $72.8 \pm 2.6$ & 15.5 & 27.99 \\
\hline Pupa & $22.8 \pm 1.9$ & $34.8 \pm 1.3$ & $48.2 \pm 1.5$ & $61.8 \pm 3.5$ & $69.2 \pm 2.8$ & 16.5 & 29.8 \\
\hline
\end{tabular}

* Mortality was expressed as mean \pm SD (standard deviation) of five replicates $(p<0.05)$ and calculated after 24 h. No mortality was observed in the control.

The efficacy of nanoparticles against different mosquitos was previously investigated. Madhiyazhagan et al. [84] reported the $30 \mathrm{ppm}$ of Ag-NPs synthesized by extract of Sargassum muticum, causing mortality for first to fourth instar and pupa, with percentages of $69.6 \% \pm 2.5 \%, 66.2 \% \pm 1.9 \%, 61.8 \% \pm 2.9 \%, 53.4 \% \pm 1.5 \%$, and $50.2 \% \pm 1.5 \%$ for Aedes aegypti, and $59.6 \% \pm 2.3 \%, 57.8 \% \pm 1.8 \%, 55.4 \% \pm 1.8 \%, 51.2 \% \pm 2.3 \%$, and $48.4 \% \pm 0.9 \%$ for Culex quinquefasciatus. Moreover, the $\mathrm{LC} 50$ values of $\mathrm{TiO}_{2}-\mathrm{NPs}_{\mathrm{s}}$ synthesized by Argemone mexicana against different instar and pupa of Aedes aegypti were 17.9 ppm (I instar), $21.7 \mathrm{ppm}$ (II), $26.1 \mathrm{ppm}$ (III), $30.04 \mathrm{ppm}$ (IV), and $35.3 \mathrm{ppm}$ (pupa), while the LC90 values were $41.6 \mathrm{ppm}$ (I instar), $51.1 \mathrm{ppm}$ (II), $56.5 \mathrm{ppm}$ (III), $62.9 \mathrm{ppm}$ (IV), and $71.7 \mathrm{ppm}$ (pupa) [85]. The LC50 values of bio-encapsulated chitosan/silver nano-complex were ranging between 54.65 and $98.17 \mathrm{ppm}$, which exhibits low larvicidal and pupicidal properties as compared with non-encapsulated chitosan/silver (LC50 ranging between 4.4 and $7.6 \mathrm{ppm}$ ) [86]. By comparing the obtained data with published studies, it can be concluded that the biosynthesized MgO-NPs were more toxic against different instar larvae and pupa at low concentrations. To the best of our knowledge, this is the first report to study the efficacy of fungal-mediated biosynthesis of MgO-NPs against Anopheles stephensi malaria vector. 
The mechanisms of MgO-NPs as mosquitocidal can be summarized into two points, first is their efficacy to produce reactive oxygen species (ROS) and second is their efficacy to damage the cell wall [87]. Interestingly, MgO-NPs are characterized by their efficacy to produce a high amount of ROS as compared to other metal oxide NPs, while being low in toxicity to humans, plants, and animals [88,89]. Therefore, MgO-NPs can be candidates as mosquitocidal agents to use in the agricultural sector to prevent or reduce the insect population through secretion of ROS without any adverse impacts on the environment and their beings. Upon contact of MgO-NPs with one stage of the A. stephensi life cycle, it breaks down into $\mathrm{Mg}^{2+}$ and $\mathrm{O}^{2-}$ ions in the surrounding environment. The oxidative stress and peroxidation of lipid are formed due to the formation of ROS because of increased $\mathrm{O}^{2-}$ ion concentrations (Figure 6) [90]. Moreover, the cellular components are discharged due to destabilization of cellular equilibrium due to an increase in the concentration of $\mathrm{Mg}^{2+}$, which ultimately leads to mosquito cell death (Figure 6) [65]. Some researchers reported that the nanoparticles react with the thiol group of amino acids or phosphate group in nucleic acid and hence deformed it, which ultimately inhibits the cell function $[26,84]$.

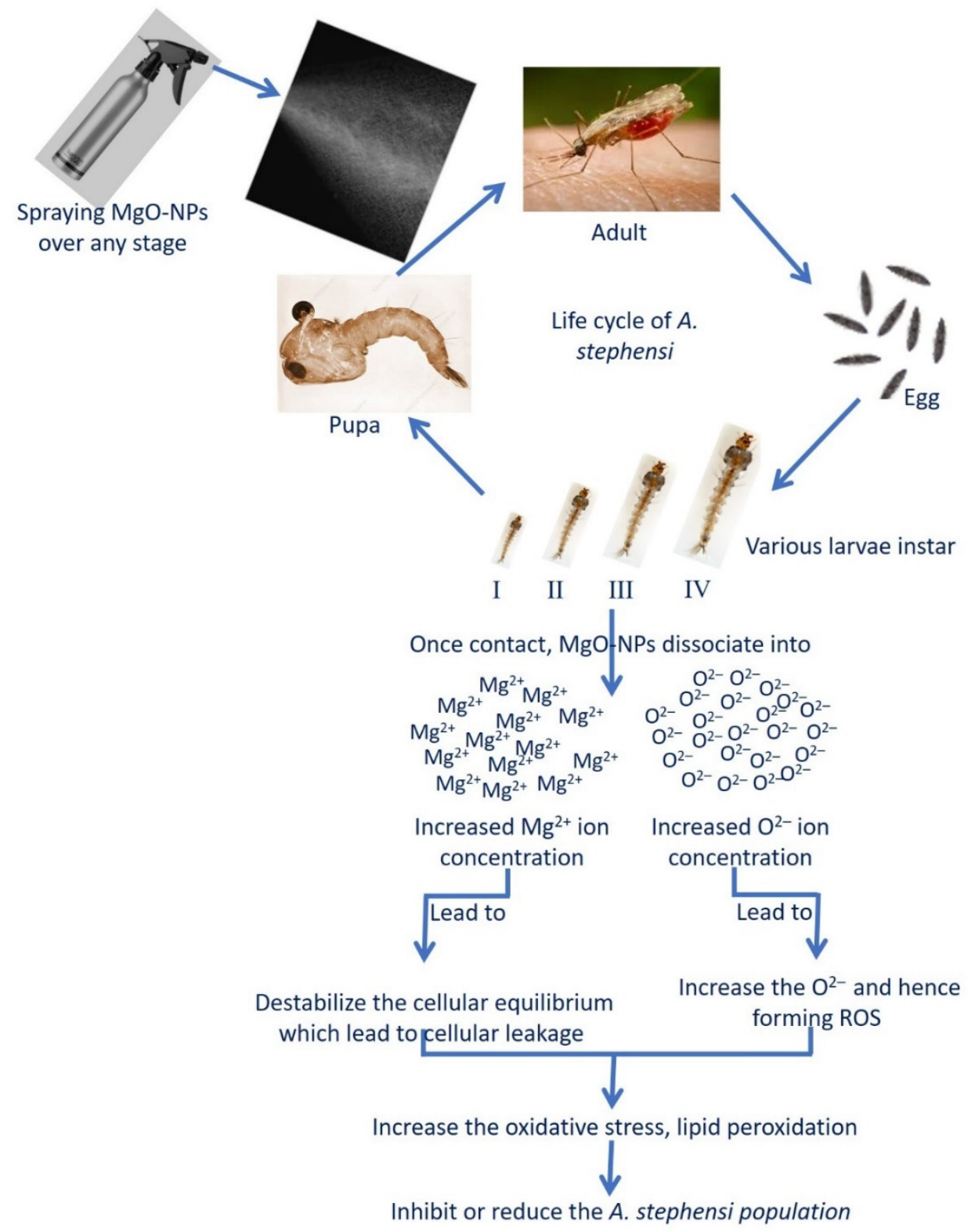

Figure 6. Prospective mechanisms of biosynthesized MgO-NPs as a mosquitocidal agent. 


\subsection{Repellent Activity}

Recently, various synthetic compounds have been analyzed to investigate their efficacy as a repellent agent against mosquitoes. However, the high cost of some proprietary chemical formulations as mosquito repellent agents, such as DEET ( $\mathrm{N}, \mathrm{N}$-diethyl-m-toluamide), decrease their usage in low-income countries [91]. Therefore, the discovery of eco-friendly and cost-effective repellent compounds is considered the main challenge. In the current study, the efficacy of biosynthesized MgO-NPs as a repellent agent was investigated. Data analysis showed that the positive control (EDDT) exhibited 100\% repellent percentages at the end of the experiment. On the other hand, all concentrations of biosynthesized $\mathrm{MgO}-\mathrm{NPs}$ exhibited 100\% repellency until $120 \mathrm{~min}$, and the activities decreased with time (Table 2). At MgO-NPs concentration of $5 \mathrm{mg} / \mathrm{com}^{2}$, the repellency reached $100 \%$ after $150 \mathrm{~min}$ and $67.6 \% \pm 1.4 \%$ after $210 \mathrm{~min}$, while at $10 \mathrm{mg} / \mathrm{cm}^{2}$, the repellency reached $80.9 \% \pm 1.9 \%$ and $59.6 \% \pm 1.5 \%$ after 120 and $210 \mathrm{~min}$, respectively. Based on obtained data, it can be recommended that the optimum MgO-NPs concentration used as a repellent agent against $A$. stephensi malaria vector is $5 \mathrm{mg} / \mathrm{cm}^{2}$.

Table 2. The repellent assay of different concentrations of biosynthesized MgO-NPs against A. stephensi.

\begin{tabular}{|c|c|c|c|c|c|c|c|c|}
\hline \multirow{2}{*}{$\begin{array}{l}\text { Concentrations of } \\
\mathrm{MgO}-\mathrm{NPs}\left(\mathrm{mg} \mathrm{cm}^{-2}\right)\end{array}$} & \multicolumn{8}{|c|}{ Repellent Percentages $(\%) \pm$ SD } \\
\hline & $15 \mathrm{~min}$ & $30 \mathrm{~min}$ & $60 \mathrm{~min}$ & $90 \mathrm{~min}$ & $120 \mathrm{~min}$ & $150 \mathrm{~min}$ & $180 \mathrm{~min}$ & $210 \mathrm{~min}$ \\
\hline 1 & $100.0 \pm 0.0$ & $100.0 \pm 0.0$ & $100.0 \pm 0.0$ & $100.0 \pm 0.0$ & $100.0 \pm 0.0$ & $69.3 \pm 1.6$ & $57.2 \pm 1.1$ & $43.1 \pm 1.6$ \\
\hline 2.5 & $100.0 \pm 0.0$ & $100.0 \pm 0.0$ & $100.0 \pm 0.0$ & $100.0 \pm 0.0$ & $100.0 \pm 0.0$ & $72.4 \pm 1.5$ & $64.2 \pm 1.6$ & $49.4 \pm 1.8$ \\
\hline 5 & $100.0 \pm 0.0$ & $100.0 \pm 0.0$ & $100.0 \pm 0.0$ & $100.0 \pm 0.0$ & $100.0 \pm 0.0$ & $100.0 \pm 0.0$ & $76.6 \pm 1.2$ & $67.6 \pm 1.4$ \\
\hline 7.5 & $100.0 \pm 0.0$ & $100.0 \pm 0.0$ & $100.0 \pm 0.0$ & $100.0 \pm 0.0$ & $100.0 \pm 0.0$ & $76.6 \pm 1.6$ & $70.0 \pm 1.6$ & $50.6 \pm 1.4$ \\
\hline 10 & $100.0 \pm 0.0$ & $100.0 \pm 0.0$ & $100.0 \pm 0.0$ & $100.0 \pm 0.0$ & $100.0 \pm 0.0$ & $80.9 \pm 1.9$ & $74.9 \pm 1.3$ & $59.6 \pm 1.5$ \\
\hline
\end{tabular}

Recently, various substances were tested as repellent agents against different mosquitos, for instance, different concentrations $\left(1,2.5\right.$, and $\left.5 \mathrm{mg} / \mathrm{cm}^{2}\right)$ of Citrullus vulgaris extract obtained by a different solvent system, including methanol, petroleum ether, benzene, and ethyl acetate, exhibited 100\% protection for times ranging between 112 to 387 min against A. stephensi [92]. Additionally, $100 \mathrm{ppm}$ of $\mathrm{TiO}_{2}-\mathrm{NPs}$ exhibited $80.4 \%$ protection against Aedes aegypti [85]. The current study provides a new eco-friendly, rapid, and low-cost approach for control of various larvae instar or pupa of A. stephensi malarial vector at low concentration, and it can also be used as a repellent agent for complete protection for $150 \mathrm{~min}$ at low concentration.

\section{Materials and Methods}

\subsection{Chemicals Used}

All chemicals in this study were analytical grade and procured from Sigma Aldrich, Cairo, Egypt. The magnesium nitrate hexahydrate $\left(\mathrm{Mg}\left(\mathrm{NO}_{3}\right)_{2} \cdot 6 \mathrm{H}_{2} \mathrm{O}\right)$ was used as a precursor for magnesium oxide nanoparticles (MgO-NPs). The different media types, Malt Extract agar (MEA) media for fungal isolation and cultivation and Muller Hinton agar media for antimicrobial activities, were ready-made (Oxoid ${ }^{\mathrm{TM}}$, Thermo-Fisher Scientific, USA). The unicellular fungi were grown in yeast extract peptone dextrose (YEPD) agar media (containing $\mathrm{g} \mathrm{L}^{-1}$ : glucose, 20; peptone, 20; yeast extract, 10; Agar, 20; distilled water, $1000 \mathrm{~mL}$ ). All biological reactions were achieved using distilled water (dis. $\mathrm{H}_{2} \mathrm{O}$ ).

\subsection{Isolation and Identification of the Fungal Strain}

The soil sample used for isolation of the fungal strain was collected from Giza Governorate, Egypt (E: 31 $\left.24^{\prime} 62.81^{\prime \prime}, \mathrm{N}: 2^{\circ} 79^{\prime} 32.09^{\prime \prime}\right)$. The isolation procedures were accomplished according to Fouda et al. [93] as follows: $1.0 \mathrm{~g}$ of collected soil was diluted in sterilized dis. $\mathrm{H}_{2} \mathrm{O}$. About $100 \mu \mathrm{L}$ of the fourth dilution was plated onto MEA plates and incubated for 3-4 days at $30 \pm 2{ }^{\circ} \mathrm{C}$. the colonies that appeared were picked up and re-inoculated onto the same media for purifications. The purified colony was preserved on an MEA slant for further use. 
The identification was accomplished by cultural and microscopic characters and confirmed using molecular identification using internal transcribed spacer (ITS) sequence analysis. The ITS rDNA region was amplified using primers for ITS1-F (5-CTTGGTCATTTAGAG GAAGTAA-3) and ITS4 (5-TCCTCCGCTTATTGATATGC-3) [94]. The PCR mixture contained: 1X PCR buffer, $0.5 \mathrm{mM} \mathrm{MgCl}$, $2.5 \mathrm{U}$ Taq DNA polymerase (QIAGEN, Germantown, MD 20874, USA), $0.25 \mathrm{mM}$ dNTP, $0.5 \mu \mathrm{L}$ of each primer, and $1 \mu \mathrm{g}$ of extracted genomic DNA. The PCR was performed in a DNA Engine Thermal Cycler (PTC-200, BIO-RAD, Hercules, CA, USA) with a program of $94^{\circ} \mathrm{C}$ for $3 \mathrm{~min}$, followed by 30 cycles of $94^{\circ} \mathrm{C}$ for $30 \mathrm{~s}, 55{ }^{\circ} \mathrm{C}$ for $30 \mathrm{~s}$, and $72{ }^{\circ} \mathrm{C}$ for $1 \mathrm{~min}$, followed by a final extension performed at $72{ }^{\circ} \mathrm{C}$ for $10 \mathrm{~min}$. The PCR product was checked for the expected sizes on a $1 \%$ agarose gel and was sequenced by Sigma Company for scientific research, Egypt, with the two primers. The sequence was compared against the GenBank database using the NCBI BLAST tool. Multiple sequence alignment was performed using the Clustal Omega software package (https: / / www.ebi.ac.uk/Tools / msa/ clustalo, last modified on 1 October 2019) and a phylogenetic tree was constructed using the neighbor-joining method with MEGA (Version 6.1) software (MEGA, Auckland, New Zeland), with confidence tested by bootstrap analysis (1000 repeats).

\subsection{Green Synthesis of $\mathrm{MgO}-\mathrm{NPS}$}

The purified fungal strains were inoculated into $100 \mathrm{~mL}$ of malt extract broth (MAB) media and incubated for 5 days at $30 \pm 2{ }^{\circ} \mathrm{C}$ and shaking state at $150 \mathrm{rpm}$. The fungal biomass was collected at the end of the incubation period through centrifugation of inoculated MAB media at $1000 \mathrm{rpm}$ for $5 \mathrm{~min}$. After that, the collected fungal biomass (10.0 g) was resuspended in $100 \mathrm{~mL}$ dis. $\mathrm{H}_{2} \mathrm{O}$ for $48 \mathrm{~h}$ at $30 \pm 2{ }^{\circ} \mathrm{C}$ and shaking state at $150 \mathrm{rpm}$. The previous suspensions were centrifuged at 10,000 rpm for $5 \mathrm{~min}$. The upper layer (fungal biomass filtrate) was collected and used for green synthesis of MgO-NPs as follows: About $76.9 \mathrm{mg}$ of $\mathrm{Mg}\left(\mathrm{NO}_{3}\right)_{2} \cdot 6 \mathrm{H}_{2} \mathrm{O}$ was dissolved in $10 \mathrm{~mL}$ dis. $\mathrm{H}_{2} \mathrm{O}$ and mixed with $90 \mathrm{~mL}$ of fungal biomass filtrate and incubated for $24 \mathrm{~h}$, to get a final concentration of $3 \mathrm{mM}$. At the end of the incubation period, the turbid white precipitate was collected and rinsed with dis. $\mathrm{H}_{2} \mathrm{O}$ to remove any impurities before being oven-dried at $400{ }^{\circ} \mathrm{C}$ for $3 \mathrm{~h}$ [26].

\subsection{Characterization of Biosynthesized $\mathrm{MgO}-\mathrm{NPS}$}

\subsubsection{UV-Vis Spectroscopy}

The intensity of color formed as a result of MgO-NPs formation was detected using UVVis spectroscopic analysis at a wavelength of $150-500 \mathrm{~nm}$. The surface plasmon resonance (SPR) was detected at the maximum observed peak. The absorbance was measured using a Jenway 6305 Spectrophotometer.

\subsubsection{X-ray Diffraction (XRD)}

The crystalline structure of fungal-mediated MgO-NPs synthesis was assessed using XRD analysis by X'Pert pro diffractometer (Philips, Eindhoven, Netherlands). The operating conditions were: $2 \theta$ values measured in ranges of $4^{\circ}$ to $80^{\circ}, \mathrm{X}$-ray radiation source was Ni-filtered $\mathrm{Cu} \mathrm{Ka}$, and the operating voltage and current were $40 \mathrm{KV}$ and $30 \mathrm{~mA}$, respectively. The average MgO-NPs sizes were measured using the Debye-Scherrer equation [95] as follows:

$$
\mathrm{D}=\mathrm{K} \lambda / \beta \operatorname{Cos} \theta
$$

where, $\mathrm{D}$ is average particle size, $\mathrm{K}$ is the Scherrer's' constant (0.9), $\lambda$ is the wavelength of $X$-ray radiation $(0.154 \mathrm{~nm})$, and $\beta$ and $\theta$ are the half of maximum intensity and Bragg's angle, respectively.

\subsubsection{Transmission Electron Microscopy (TEM)}

The shapes and sizes of biosynthesized MgO-NPs were investigated using TEM analysis (JEOL 1010, Japan, acceleration voltage of $120 \mathrm{KV}$ ). A drop of MgO-NPs solution 
was loaded on the carbon-copper grid and it underwent vacuum desiccation for $24 \mathrm{~h}$, and after that, was placed onto a specimen holder [96].

\subsubsection{Dynamic Light Scattering (DLS)}

The distribution and sizes of MgO-NPs in colloidal solution were detected by DLS analysis. The sample was subjected to measurement by Zeta sizer nano series (Nano ZS), Malvern, UK.

\subsubsection{Energy Dispersive X-ray (EDX) Analysis}

The qualitative and quantitative composition of MgO-NPs were assessed using energy dispersive X-ray (SEM-EDX) (JEOL, JSM-6360LA, Tokio, Japan).

\subsubsection{Fourier Transform Infrared (FT-IR)}

The functional groups present in fungal biomass filtrate and involved in reducing, capping, and stabilizing MgO-NPs were investigated using Fourier transform infrared (FTIR) spectroscopy (Agilent system Cary 660 FT-IR model, Agilent, Santa Clara, CA, USA). The MgO-NPs sample was mixed with $\mathrm{KBr}$ and pressured to form a disk that scanned in the range of 400 to $4000 \mathrm{~cm}^{-1}$.

\subsubsection{X-Ray Photoelectron Spectroscopy (XPS)}

The X-ray photoelectron spectroscopy (XPS) analyses were analyzed by an ESCALAB 250XI ${ }^{+}$instrument (Thermo Fischer Scientific, Inc., Waltham, MA, USA) connected with monochromatic X-ray Al $\mathrm{K} \alpha$ radiation $(1486.6 \mathrm{eV})$. The analysis was conducted under the following conditions: the size of the spot was $500 \mu \mathrm{m}$, the samples were prepared under a pressure adjusted to $10^{-8}$ mbar, the energy was calibrated with $A g 3 \mathrm{~d}_{5 / 2}$ signal $(\triangle \mathrm{BE}: 0.45 \mathrm{eV})$ and $\mathrm{C} 1 \mathrm{~s}$ signal $(\triangle \mathrm{BE}: 0.82 \mathrm{eV})$, and the full- and narrow-spectrum pass energies were 50 and $20 \mathrm{eV}$, respectively $[66,97]$.

\subsection{Antimicrobial Activity}

The antimicrobial activity of MgO-NPs synthesized by fungal metabolites was investigated against Gram-positive pathogenic microbes (Staphylococcus aureus ATCC 6538, Bacillus subtilis ATCC 6633), Gram-negative pathogenic microbes (Pseudomonas aeruginosa ATCC 9022, Escherichia coli ATCC 8739), and unicellular fungi (Candida albicans ATCC 10231) [15]. A $100 \mathrm{~mL}$ of Muller Hinton agar media (for bacterial growth) and yeast extract peptone dextrose (YEPD) agar media (for C. albicans growth) was inoculated by $50 \mu \mathrm{L}$ of overnight culture. The inoculated media were poured into sterilized Petri plates under sterilized conditions. Three wells $(0.7 \mathrm{~cm}$ diameter) were cut in the seeded Muller Hinton or YEPD agar plates and filled with $100 \mu \mathrm{L}$ of biosynthesized MgO-NPs $\left(200 \mu \mathrm{g} \mathrm{mL}^{-1}\right)$. Different concentrations of MgO-NPs (150, 100, 50, and $25 \mu \mathrm{g} \mathrm{mL}^{-1}$ ) were prepared to detect the minimum inhibitory concentration (MIC). The loaded Muller Hinton plates were kept in the refrigerator for $1 \mathrm{~h}$ before incubation at $35^{\circ} \mathrm{C}$ for $24 \mathrm{~h}$. The results were recorded as zones of inhibition (ZOIs) around each well by $\mathrm{mm}$ [8]. The experiments were performed in triplicate.

\subsection{Mosquitocidal Assay}

\subsubsection{Rearing of Anopheles stephensi}

The larvae of Anopheles stephensi were purchased from the Medical Entomology Lab., Dokki, Giza, Egypt, and subjected to rearing again in the Medical Entomology Lab., AnimalHouse, Department of Zoology and Entomology, Faculty of Science, Al-Azhar University, Cairo, Egypt.

Larvae to adult mosquitoes were reared at $27 \pm 2{ }^{\circ} \mathrm{C}, 75-85 \%$ relative humidity $(\mathrm{RH})$, and a photoperiod of 14: 10 light: dark condition. The larvae were fed daily on $5 \mathrm{~g}$ of 3:1 ground dog biscuit: brewer's yeast. The emerging pupae were collected and put into a plastic cup containing $500 \mathrm{~mL}$ of water and transferred to inside a screen 
cage $(90 \mathrm{~cm}$ length $\times 90 \mathrm{~cm}$ height $\times 90 \mathrm{~cm}$ width) until adults emerged, which fed on $10 \%(w / v)$ sucrose (replaced every two days to avoid the fungal growth). Five-day emergence adults were starved for 12-24 $\mathrm{h}$ and then allowed to be fed on the cattle-originated blood. About $5 \mathrm{~mL}$ of cattle blood was poured onto the membrane feeder and the blood temperature was adjusted to $37^{\circ} \mathrm{C}$. The blood membrane feeder was placed into the cage for $1-2 \mathrm{~h}$ and removed. The egg collection cup containing filter paper and $10 \mathrm{~mL}$ distilled water was put inside the cage for oviposition by female mosquitoes [98].

\subsubsection{Larvicidal/Pupicidal Assay}

The toxicity of different concentrations $\left(25,20,15,10\right.$, and $\left.5 \mu \mathrm{g} \mathrm{mL}{ }^{-1}\right)$ of biosynthesized $\mathrm{MgO}-\mathrm{NPs}$ was investigated against various larvae instar (I, II, III, or IV instars) and pupa of A. stephensi. Briefly, 25 larvae or pupa were put into the glass cup containing $500 \mathrm{~mL}$ dechlorinated water and supplemented with $5 \mathrm{~mL}$ of MgO-NPs $\left(25 \mu \mathrm{g} \mathrm{mL}{ }^{-1}\right)$ and $0.5 \mathrm{mg}$ of the larvae food. The previous step was repeated for each MgO-NPs concentration and each experiment was repeated five times with all larvae instars and pupae. The control was run alongside each experiment without adding MgO-NPs. The mortality percentages (\%) were calculated after $24 \mathrm{~h}$ according to the following equation:

$$
\text { Mortality percentages }(\%)=\frac{\text { Number of dead individuals }}{\text { Number of treated individuals }} \times 100
$$

\subsubsection{Repellent Activity}

The repellent activity of different prepared MgO-NPs concentrations $(10,7.5,5,2.5$, and $1.0 \mathrm{mg} \mathrm{cm}^{-1}$ ) was assessed according to the method of Murugan et al. [85] using a cotton pad. Briefly, the cotton pad was firstly soaked in cattle-originated blood, followed by painting with different prepared MgO-NPs concentrations, separately. Another blood cotton pad was painted with DEET (N, N, diethyl-meta-toulamide) (Johnson Wax Egypt), which served as a positive control. The treated and control cotton pads were placed into the standard cage $\left(30 \times 30 \times 30 \mathrm{~cm}^{3}\right)$ containing 50 A. stephensi starved females for $210 \mathrm{~min}$. The experiment was repeated three times for each concentration used. The repellency of treated and control cotton pads was calculated after 15, 30, 60, 90, 120, 150, 180, and $210 \mathrm{~min}$ using the following equation:

$$
\text { Repellency percentages }(\%)=\frac{\mathrm{C}-\mathrm{T}}{\mathrm{C}} \times 100
$$

where $C$ denotes the total number of mosquitos before treatment, and $\mathrm{T}$ denotes the total number of mosquitos after treatment.

\subsection{Statistical Analysis}

All results presented here are the means of three independent replicates. Data were subjected to statistical analysis by the statistical package SPSS v17. The mean difference comparison between the treatments was analyzed by $t$-test or the analysis of variance (ANOVA) and subsequently, by Tukey's HSD test, at $p<0.05$.

\section{Conclusions}

In the current study, the metabolites secreted by Penicillium chrysogenum strain A2 were used for reducing, capping, and stabilizing MgO-NPs. The characterization of asformed MgO-NPs was accomplished using UV-Vis, XRD, TEM, DLS, EDX, FT-IR, and XPS analyses. The maximum SPR for biosynthesized MgO-NPs was observed at $250 \mathrm{~nm}$. Additionally, a crystalline nature, well-dispersed, spherical shape with an average size of $16.9 \pm 7.5 \mathrm{~nm}$ was detected by XRD, DLS, and TEM analyses. The presence of Mg and O ions at various pending energies was confirmed by EDX and XPS analyses. Data showed that the biological activities of biosynthesized MgO-NPs were dependent on time and concentration. The biogenic MgO-NPs showed antimicrobial activities against pathogenic 
microbes represented by Staphylococcus aureus, Bacillus subtilis, Pseudomonas aeruginosa, Escherichia coli, and Candida albicans, with a varied zone of inhibition. Data analysis showed that Gram-negative bacteria were more sensitive to MgO-NPs than Gram-positive bacteria and unicellular fungi. The MIC value for B. subtilis, S. aureus, and C. albicans was $100 \mu \mathrm{g} \mathrm{mL}^{-1}$, with ZOIs of $8.7 \pm 0.6,8.2 \pm 0.3$, and $9.3 \pm 0.9 \mathrm{~mm}$, respectively. Whereas the MIC value for Gram-negative bacteria, P. aeruginosa, and E. coli was $50 \mu \mathrm{g} \mathrm{mL}^{-1}$, with ZOIs of $9.7 \pm 0.5$ and $8.2 \pm 0.3 \mathrm{~mm}$, respectively. Moreover, the biogenic MgO-NPs exhibited larvicidal, pupicidal, and repellent activity against Anopheles stephensi malaria vector at low concentrations. The LC50 and LC90 values for different larva instar (I-IV) ranged between 12.4 and 15.6 ppm and 22.3 and 27.9 ppm, respectively. Additionally, the LC50 and LC90 values for pupa were 16.5 and $29.8 \mathrm{ppm}$, respectively. Interestingly, the MgO-NPs concentration of $5 \mathrm{mg} \mathrm{cm}^{2}$ exhibited the highest repellent percentages, of $100 \%$ after $150 \mathrm{~min}$ and $67.6 \% \pm 1.4 \%$ after $210 \mathrm{~min}$. According to the obtained data, it can be concluded that P. chrysogenum has the ability to form MgO-NPs which exhibit high potentiality to control pathogenic microbes and malarial vector insects.

Author Contributions: Conceptualization, S.E.-D.H. and A.F.; methodology, S.E.-D.H., A.F., E.S., A.M.E., M.G.B., S.A. and M.A.A.; software, S.E.-D.H., A.F., E.S., A.M.E., M.G.B. and M.A.A.; validation, S.E.-D.H., A.F., E.S., A.M.E., M.G.B. and M.A.A.; formal analysis, S.E.-D.H., A.F., E.S., A.M.E., M.G.B., M.A.A., M.F.H. and S.A.; investigation, S.E.-D.H., A.F., E.S., A.M.E., M.G.B. and M.A.A.; resources, S.E.-D.H., A.F., E.S., A.M.E., M.G.B., M.A.A., M.F.H. and S.A.; data curation, S.E.-D.H., A.F., E.S., A.M.E., M.G.B. and M.A.A.; writing-original draft preparation, S.E.-D.H., A.F., E.S., A.M.E., M.G.B., M.A.A., M.F.H. and M.F.A.; writing-review and editing, S.E.-D.H., A.F., A.M.E., M.G.B., M.A.A., M.F.H. and M.F.A.; visualization, S.E.-D.H., A.F., E.S., A.M.E., M.G.B., M.A.A. and M.F.H.; supervision, S.E.-D.H. and A.F.; project administration, S.E.-D.H. and A.F.; funding acquisition, M.F.A. All authors have read and agreed to the published version of the manuscript.

Funding: This research received no external funding.

Institutional Review Board Statement: Not applicable.

Informed Consent Statement: Not applicable.

Data Availability Statement: The data presented in this study are available on request from the corresponding author.

Acknowledgments: The authors extend their appreciation to the Taif University for funding this work through Taif University Researchers Supporting Project number (TURSP-2020/111), Taif University, Taif, Saudi Arabia. Authors extend their appreciation to Mamdouh Salem El-Gamal (Head of Microbial Physiology Lab), Botany and Microbiology Department, Faculty of Science, Al-Azhar University, Cairo, Egypt, for the great help in the current study.

Conflicts of Interest: The authors declare no conflict of interest.

\section{References}

1. Rani, P.; Kaur, G.; Rao, K.V.; Singh, J.; Rawat, M. Impact of Green Synthesized Metal Oxide Nanoparticles on Seed Germination and Seedling Growth of Vigna radiata (Mung Bean) and Cajanus cajan (Red Gram). J. Inorg. Organomet. Polym. Mater. 2020, 30, 4053-4062. [CrossRef]

2. Fouda, A.; Abdel-Maksoud, G.; Abdel-Rahman, M.A.; Salem, S.S.; Hassan, S.E.-D.; El-Sadany, M.A.-H. Eco-friendly approach utilizing green synthesized nanoparticles for paper conservation against microbes involved in biodeterioration of archaeological manuscript. Int. Biodeterior. Biodegrad. 2019, 142, 160-169. [CrossRef]

3. Pham, D.T.N.; Khan, F.; Phan, T.T.V.; Park, S.-K.; Manivasagan, P.; Oh, J.; Kim, Y.-M. Biofilm inhibition, modulation of virulence and motility properties by FeOOH nanoparticle in Pseudomonas aeruginosa. Braz. J. Microbiol. 2019, 50, 791-805. [CrossRef] [PubMed]

4. Raliya, R.; Tarafdar, J.; Choudhary, K.K.; Mal, P.; Raturi, A.; Gautam, R.; Singh, S. Synthesis of MgO Nanoparticles Using Aspergillus Tubingensis TFR-3. J. Bionanosci. 2014, 8. [CrossRef]

5. Salem, S.S.; Fouda, A. Green Synthesis of Metallic Nanoparticles and Their Prospective Biotechnological Applications: An Overview. Biol. Trace Elem. Res. 2021, 199, 344-370. [CrossRef]

6. Fatimah, I. Biosynthesis and characterization of $\mathrm{ZnO}$ nanoparticles using rice bran extract as low-cost templating agent. J. Eng. Sci. Technol. 2018, 13, 409-420. 
7. Eid, A.M.; Fouda, A.; Abdel-Rahman, M.A.; Salem, S.S.; Elsaied, A.; Oelmüller, R.; Hijri, M.; Bhowmik, A.; Elkelish, A.; Hassan, S.E.-D. Harnessing Bacterial Endophytes for Promotion of Plant Growth and Biotechnological Applications: An Overview. Plants 2021, 10, 935. [CrossRef]

8. El-Belely, E.F.; Farag, M.M.S.; Said, H.A.; Amin, A.S.; Azab, E.; Gobouri, A.A.; Fouda, A. Green Synthesis of Zinc Oxide Nanoparticles (ZnO-NPs) Using Arthrospira platensis (Class: Cyanophyceae) and Evaluation of their Biomedical Activities. Nanomaterials 2021, 11, 95. [CrossRef] [PubMed]

9. Lashin, I.; Fouda, A.; Gobouri, A.A.; Azab, E.; Mohammedsaleh, Z.M.; Makharita, R.R. Antimicrobial and In Vitro Cytotoxic Efficacy of Biogenic Silver Nanoparticles (Ag-NPs) Fabricated by Callus Extract of Solanum incanum L. Biomolecules 2021, 11, 341. [CrossRef] [PubMed]

10. Velgosova, O.; Veselovský, L. Synthesis of Ag nanoparticle using R. officinalis, U. dioica and V. vitis-idaea extracts. Mater. Lett. 2019, 248, 150-152. [CrossRef]

11. Velgosova, O.; Dolinská, S.; Mražíková, A.; Briančin, J. Effect of P. kessleri extracts treatment on AgNPs synthesis. Inorg. Nano-Met. Chem. 2020, 50, 842-852. [CrossRef]

12. Clarance, P.; Luvankar, B.; Sales, J.; Khusro, A.; Agastian, P.; Tack, J.C.; Al Khulaifi, M.M.; Al-Shwaiman, H.A.; Elgorban, A.M.; Syed, A.; et al. Green synthesis and characterization of gold nanoparticles using endophytic fungi Fusarium solani and its in-vitro anticancer and biomedical applications. Saudi J. Biol. Sci. 2020, 27, 706-712. [CrossRef] [PubMed]

13. Hassan, S.E.L.D.; Salem, S.S.; Fouda, A.; Awad, M.A.; El-Gamal, M.S.; Abdo, A.M. New approach for antimicrobial activity and bio-control of various pathogens by biosynthesized copper nanoparticles using endophytic actinomycetes. J. Radiat. Res. Appl. Sci. 2018, 11, 262-270. [CrossRef]

14. Mohamed, A.A.; Fouda, A.; Abdel-Rahman, M.A.; Hassan, S.E.-D.; El-Gamal, M.S.; Salem, S.S.; Shaheen, T.I. Fungal strain impacts the shape, bioactivity and multifunctional properties of green synthesized zinc oxide nanoparticles. Biocatal. Agric. Biotechnol. 2019, 19, 101103. [CrossRef]

15. Aref, M.S.; Salem, S.S. Bio-callus synthesis of silver nanoparticles, characterization, and antibacterial activities via Cinnamomum camphora callus culture. Biocatal. Agric. Biotechnol. 2020, 27, 101689. [CrossRef]

16. Fouda, A.; Hassan, S.E.-D.; Saied, E.; Azab, M.S. An eco-friendly approach to textile and tannery wastewater treatment using maghemite nanoparticles $\left(\gamma-\mathrm{Fe}_{2} \mathrm{O}_{3}-\mathrm{NPs}\right)$ fabricated by Penicillium expansum strain $(\mathrm{K}-\mathrm{w})$. J. Environ. Chem. Eng. 2021, 9, 104693. [CrossRef]

17. Velgosova, O.; Mudra, E.; Vojtko, M. Preparing, Characterization and Anti-Biofilm Activity of Polymer Fibers Doped by Green Synthesized AgNPs. Polymers 2021, 13, 605. [CrossRef]

18. Spagnoletti, F.N.; Spedalieri, C.; Kronberg, F.; Giacometti, R. Extracellular biosynthesis of bactericidal Ag/ AgCl nanoparticles for crop protection using the fungus Macrophomina phaseolina. J. Environ. Manag. 2019, 231, 457-466. [CrossRef]

19. Fouda, A.; Abdel-Maksoud, G.; Saad, H.A.; Gobouri, A.A.; Mohammedsaleh, Z.M.; El-Sadany, M.A. The efficacy of silver nitrate (AgNO3) as a coating agentto protect paper against high deteriorating microbes. Catalysts 2021, 11, 310. [CrossRef]

20. Khalil, A.M.; Hassan, S.E.; Alsharif, S.M.; Eid, A.M.; Ewais, E.E.; Azab, E.; Gobouri, A.A.; Elkelish, A.; Fouda, A. Isolation and Characterization of Fungal Endophytes Isolated from Medicinal Plant Ephedra pachyclada as Plant Growth-Promoting. Biomolecules 2021, 11, 140. [CrossRef]

21. Fouda, A.H.; Hassan, S.E.-D.; Eid, A.M.; Ewais, E.E.-D. Biotechnological applications of fungal endophytes associated with medicinal plant Asclepias sinaica (Bioss.). Ann. Agric. Sci. 2015, 60, 95-104. [CrossRef]

22. Fouda, A.; Salem, S.S.; Wassel, A.R.; Hamza, M.F.; Shaheen, T.I. Optimization of green biosynthesized visible light active $\mathrm{CuO} / \mathrm{ZnO}$ nano-photocatalysts for the degradation of organic methylene blue dye. Heliyon 2020, 6, e04896. [CrossRef]

23. Tso, C.P.; Zhung, C.M.; Shih, Y.H.; Tseng, Y.M.; Wu, S.C.; Doong, R.A. Stability of metal oxide nanoparticles in aqueous solutions. Water Sci. Technol. J. Int. Assoc. Water Pollut. Res. 2010, 61, 127-133. [CrossRef]

24. Ivask, A.; Titma, T.; Visnapuu, M.; Vija, H.; Kakinen, A.; Sihtmae, M.; Pokhrel, S.; Madler, L.; Heinlaan, M.; Kisand, V.; et al. Toxicity of Metal Oxide Nanoparticles to Three Mammalian Cell Types In Vitro. Curr. Top. Med. Chem. 2015, 15, 1914-1929. [CrossRef]

25. Mirzaei, H.; Davoodnia, A. Microwave Assisted Sol-Gel Synthesis of MgO Nanoparticles and Their Catalytic Activity in the Synthesis of Hantzsch 1,4-Dihydropyridines. Chin. J. Catal. 2012, 33, 1502-1507. [CrossRef]

26. Fouda, A.; Hassan, S.E.-D.; Saied, E.; Hamza, M.F. Photocatalytic degradation of real textile and tannery effluent using biosynthesized magnesium oxide nanoparticles (MgO-NPs), heavy metal adsorption, phytotoxicity, and antimicrobial activity. J. Environ. Chem. Eng. 2021, 9, 105346. [CrossRef]

27. Hassan, S.E.-D.; Fouda, A.; Saied, E.; Farag, M.M.S.; Eid, A.M.; Barghoth, M.G.; Awad, M.A.; Hamza, M.F.; Awad, M.F. Rhizopus Oryzae-mediated green synthesis of magnesium oxide nanoparticles (MgO-NPs): A promising tool for antimicrobial, mosquitocidal action, and tanning effluent treatment. J. Fungi 2021, 7, 372. [CrossRef]

28. Di, D.R.; He, Z.Z.; Sun, Z.Q.; Liu, J. A new nano-cryosurgical modality for tumor treatment using biodegradable MgO nanoparticles. Nanomed. Nanotechnol. Biol. Med. 2012, 8, 1233-1241. [CrossRef]

29. Khan, A.; Shabbier, D.; Ahmad, P.; Khandaker, M.; Faruque, M.R.; Din, I.U. Biosynthesis and antibacterial activity of MgO-NPs produced from Camellia-sinensis leaves extract. Mater. Res. Express 2020, 8. [CrossRef]

30. Cai, L.; Chen, J.; Liu, Z.; Wang, H.; Yang, H.; Ding, W. Magnesium Oxide Nanoparticles: Effective Agricultural Antibacterial Agent Against Ralstonia solanacearum. Front. Microbiol. 2018, 9. [CrossRef] [PubMed] 
31. Ammulu, M.A.; Vinay Viswanath, K.; Giduturi, A.K.; Vemuri, P.K.; Mangamuri, U.; Poda, S. Phytoassisted synthesis of magnesium oxide nanoparticles from Pterocarpus marsupium rox.b heartwood extract and its biomedical applications. J. Genet. Eng. Biotechnol. 2021, 19, 21. [CrossRef]

32. Moubasher, A.H.; Moustafa, A.F. A survey of Egyptian soil fungi with special reference to Aspergillus, Penicillium and Penicilliumrelated genera. Trans. Br. Mycol. Soc. 1970, 54, 35-44. [CrossRef]

33. Housseiny, M.M.; Gomaa, E.Z. Enhancement of Antimicrobial and Antitumor Activities of Zinc Nanoparticles Biosynthesized by Penicillium chrysogenum AUMC 10608 Using Gamma Radiation. Egypt. J. Bot. 2019, 59, 319-337. [CrossRef]

34. Barabadi, H.; Kobarfard, F.; Vahidi, H. Biosynthesis and Characterization of Biogenic Tellurium Nanoparticles by Using Penicillium chrysogenum PTCC 5031: A Novel Approach in Gold Biotechnology. Iran. J. Pharm. Res. IJPR 2018, 17, 87-97.

35. Grijseels, S.; Nielsen, J.C.; Nielsen, J.; Larsen, T.O.; Frisvad, J.C.; Nielsen, K.F.; Frandsen, R.J.N.; Workman, M. Physiological characterization of secondary metabolite producing Penicillium cell factories. Fungal Biol. Biotechnol. 2017, 4, 8. [CrossRef] [PubMed]

36. Lopes, F.C.; Tichota, D.M.; Sauter, I.P.; Meira, S.M.M.; Segalin, J.; Rott, M.B.; Rios, A.O.; Brandelli, A. Active metabolites produced by Penicillium chrysogenum IFL1 growing on agro-industrial residues. Ann. Microbiol. 2013, 63, 771-778. [CrossRef]

37. Khanra, K.; Panja, S.; Choudhuri, I.; Bhattacharyya, N. Evaluation of Antibacterial Activity and Cytotoxicity of Green Synthesized Silver Nanoparticles Using Scoparia dulcis. Nano Biomed. Eng. 2015, 7, 128-133. [CrossRef]

38. Essien, E.R.; Atasie, V.N.; Okeafor, A.O.; Nwude, D.O. Biogenic synthesis of magnesium oxide nanoparticles using Manihot esculenta (Crantz) leaf extract. Int. Nano Lett. 2020, 10, 43-48. [CrossRef]

39. Fedlheim, D.L.; Foss, C.A. Metal Nanoparticles: Synthesis, Characterization, and Applications; CRC Press: Boca Raton, FL, USA, 2001.

40. Jeevanandam, J.; Chan, Y.S.; Danquah, M.K. Biosynthesis and characterization of MgO nanoparticles from plant extracts via induced molecular nucleation. New J. Chem. 2017, 41, 2800-2814. [CrossRef]

41. Abdallah, Y.; Ogunyemi, S.O.; Abdelazez, A.; Zhang, M.; Hong, X.; Ibrahim, E.; Hossain, A.; Fouad, H.; Li, B.; Chen, J. The Green Synthesis of MgO Nano-Flowers Using Rosmarinus officinalis L. (Rosemary) and the Antibacterial Activities against Xanthomonas oryzae pv. oryzae. BioMed Res. Int. 2019, 2019, 5620989. [CrossRef]

42. Sivaselvam, S.; Premasudha, P.; Viswanathan, C.; Ponpandian, N. Enhanced removal of emerging pharmaceutical contaminant ciprofloxacin and pathogen inactivation using morphologically tuned $\mathrm{MgO}$ nanostructures. J. Environ. Chem. Eng. 2020, 8, 104256. [CrossRef]

43. Lekota, M.W.; Dimpe, K.M.; Nomngongo, P.N. MgO-ZnO/carbon nanofiber nanocomposite as an adsorbent for ultrasoundassisted dispersive solid-phase microextraction of carbamazepine from wastewater prior to high-performance liquid chromatographic detection. J. Anal. Sci. Technol. 2019, 10, 25. [CrossRef]

44. Dhaouadi, H.; Chaabane, H.; Touati, F. $\mathrm{Mg}(\mathrm{OH})_{2}$ Nanorods Synthesized by A Facile Hydrothermal Method in the Presence of CTAB. Nano-Micro Lett. 2011, 3, 153-159. [CrossRef]

45. Fouda, A.; Hassan, S.E.-D.; Abdel-Rahman, M.A.; Farag, M.M.S.; Shehal-deen, A.; Mohamed, A.A.; Alsharif, S.M.; Saied, E.; Moghanim, S.A.; Azab, M.S. Catalytic degradation of wastewater from the textile and tannery industries by green synthesized hematite $\left(\alpha-\mathrm{Fe}_{2} \mathrm{O}_{3}\right)$ and magnesium oxide $(\mathrm{MgO})$ nanoparticles. Curr. Res. Biotechnol. 2021, 3, 29-41. [CrossRef]

46. Moorthy, S.K.; Ashok, C.H.; Rao, K.V.; Viswanathan, C. Synthesis and Characterization of Mgo Nanoparticles by Neem Leaves through Green Method. Mater. Today: Proc. 2015, 2, 4360-4368. [CrossRef]

47. Eppler, A.; Zhu, J.; Anderson, E.; Somorjai, G. Model catalysts fabricated by electron beam lithography: AFM and TPD surface studies and hydrogenation/dehydrogenation of cyclohexene $+\mathrm{H}_{2}$ on a Pt nanoparticle array supported by silica. Top. Catal. 2000, 13, 33-41. [CrossRef]

48. Bindhu, M.R.; Umadevi, M.; Kavin Micheal, M.; Arasu, M.V.; Abdullah Al-Dhabi, N. Structural, morphological and optical properties of $\mathrm{MgO}$ nanoparticles for antibacterial applications. Mater. Lett. 2016, 166, 19-22. [CrossRef]

49. Huang, L.; Li, D.; Lin, Y.; Evans, D.G.; Duan, X. Influence of nano-MgO particle size on bactericidal action against Bacillus subtilis var. niger. Chin. Sci. Bull. 2005, 50, 514-519. [CrossRef]

50. Tomaszewska, E.; Soliwoda, K.; Kadziola, K.; Tkacz-Szczesna, B.; Celichowski, G.; Cichomski, M.; Szmaja, W.; Grobelny, J. Detection Limits of DLS and UV-Vis Spectroscopy in Characterization of Polydisperse Nanoparticles Colloids. J. Nanomater. 2013, 2013, 313081. [CrossRef]

51. Fouda, A.; Hassan, S.E.; Abdo, A.M.; El-Gamal, M.S. Antimicrobial, Antioxidant and Larvicidal Activities of Spherical Silver Nanoparticles Synthesized by Endophytic Streptomyces spp. Biol. Trace Elem. Res. 2020, 195, 707-724. [CrossRef] [PubMed]

52. Salem, S.S.; El-Belely, E.F.; Niedbała, G.; Alnoman, M.M.; Hassan, S.E.-D.; Eid, A.M.; Shaheen, T.I.; Elkelish, A.; Fouda, A. Bactericidal and In-Vitro Cytotoxic Efficacy of Silver Nanoparticles (Ag-NPs) Fabricated by Endophytic Actinomycetes and Their Use as Coating for the Textile Fabrics. Nanomaterials 2020, 10, 2082. [CrossRef] [PubMed]

53. Singh, T.; Jyoti, K.; Patnaik, A.; Singh, A.; Chauhan, R.; Chandel, S.S. Biosynthesis, characterization and antibacterial activity of silver nanoparticles using an endophytic fungal supernatant of Raphanus sativus. J. Genet. Eng. Biotechnol. 2017, 15, 31-39. [CrossRef]

54. Eid, A.M.; Fouda, A.; Niedbała, G.; Hassan, S.E.; Salem, S.S.; Abdo, A.M.; Hetta, H.F.; Shaheen, T.I. Endophytic Streptomyces laurentii Mediated Green Synthesis of Ag-NPs with Antibacterial and Anticancer Properties for Developing Functional Textile Fabric Properties. Antibiotics 2020, 9, 641. [CrossRef] [PubMed]

55. Dobrucka, R. Synthesis of MgO Nanoparticles Using Artemisia abrotanum Herba Extract and Their Antioxidant and Photocatalytic Properties. Iran. J. Sci. Technol. Trans. Sci. 2018, 42, 547-555. [CrossRef] 
56. Alsharif, S.M.; Salem, S.S.; Abdel-Rahman, M.A.; Fouda, A.; Eid, A.M.; El-Din Hassan, S.; Awad, M.A.; Mohamed, A.A. Multifunctional properties of spherical silver nanoparticles fabricated by different microbial taxa. Heliyon 2020, 6, e03943. [CrossRef] [PubMed]

57. Shaheen, T.I.; Fouda, A.; Salem, S.S. Integration of Cotton Fabrics with Biosynthesized CuO Nanoparticles for Bactericidal Activity in the Terms of Their Cytotoxicity Assessment. Ind. Eng. Chem. Res. 2021, 60, 1553-1563. [CrossRef]

58. Ramanujam, K.; Sundrarajan, M. Antibacterial effects of biosynthesized MgO nanoparticles using ethanolic fruit extract of Emblica officinalis. J. Photochem. Photobiol. B Biol. 2014, 141, 296-300. [CrossRef] [PubMed]

59. Hamza, M. Uranium recovery from concentrated chloride solution produced from direct acid leaching of calcareous shale, Allouga ore materials, southwestern Sinai, Egypt. J. Radioanal. Nucl. Chem. 2018, 315. [CrossRef]

60. Coates, J. Interpretation of infrared spectra, a practical approach. Encycl. Anal. Chem. Appl. Theory Instrum. 2006. [CrossRef]

61. Hamza, M.F.; Salih, K.A.M.; Abdel-Rahman, A.A.H.; Zayed, Y.E.; Wei, Y.; Liang, J.; Guibal, E. Sulfonic-functionalized algal/PEI beads for scandium, cerium and holmium sorption from aqueous solutions (synthetic and industrial samples). Chem. Eng. J. 2021, 403, 126399. [CrossRef]

62. Hamza, M.F.; Wei, Y.; Mira, H.I.; Abdel-Rahman, A.A.H.; Guibal, E. Synthesis and adsorption characteristics of grafted hydrazinyl amine magnetite-chitosan for $\mathrm{Ni}(\mathrm{II})$ and $\mathrm{Pb}$ (II) recovery. Chem. Eng. J. 2019, 362, 310-324. [CrossRef]

63. Karthik, K.; Dhanuskodi, S.; Gobinath, C.; Prabukumar, S.; Sivaramakrishnan, S. Fabrication of MgO nanostructures and its efficient photocatalytic, antibacterial and anticancer performance. J. Photochem. Photobiol. B Biol. 2019, 190, 8-20. [CrossRef]

64. Hamza, M.F.; Wei, Y.; Benettayeb, A.; Wang, X.; Guibal, E. Efficient removal of uranium, cadmium and mercury from aqueous solutions using grafted hydrazide-micro-magnetite chitosan derivative. J. Mater. Sci. 2020, 55, 4193-4212. [CrossRef]

65. Pugazhendhi, A.; Prabhu, R.; Muruganantham, K.; Shanmuganathan, R.; Natarajan, S. Anticancer, antimicrobial and photocatalytic activities of green synthesized magnesium oxide nanoparticles (MgONPs) using aqueous extract of Sargassum wightii. J. Photochem. Photobiol. B Biol. 2019, 190, 86-97. [CrossRef] [PubMed]

66. Wei, Y.; Salih, K.A.M.; Lu, S.; Hamza, M.F.; Fujita, T.; Vincent, T.; Guibal, E. Amidoxime Functionalization of Algal/Polyethyleneimine Beads for the Sorption of Sr(II) from Aqueous Solutions. Molecules 2019, 24, 3893. [CrossRef] [PubMed]

67. Salih, K.A.M.; Hamza, M.F.; Mira, H.; Wei, Y.; Gao, F.; Atta, A.M.; Fujita, T.; Guibal, E. Nd(III) and Gd(III) sorption on mesoporous amine-functionalized polymer $/ \mathrm{SiO}_{2}$ composite. Molecules 2021, 26, 1049. [CrossRef]

68. Hamza, M.F.; Lu, S.; Salih, K.A.M.; Mira, H.; Dhmees, A.S.; Fujita, T.; Wei, Y.; Vincent, T.; Guibal, E. As(V) sorption from aqueous solutions using quaternized algal/polyethyleneimine composite beads. Sci. Total Environ. 2020, 719, 137396. [CrossRef]

69. Wei, Y.; Rakhatkyzy, M.; Salih, K.A.M.; Wang, K.; Hamza, M.F.; Guibal, E. Controlled bi-functionalization of silica microbeads through grafting of amidoxime/methacrylic acid for Sr(II) enhanced sorption. Chem. Eng. J. 2020, 402, 125220. [CrossRef]

70. Lu, S.; Chen, L.; Hamza, M.F.; He, C.; Wang, X.; Wei, Y.; Guibal, E. Amidoxime functionalization of a poly(acrylonitrile)/silica composite for the sorption of $\mathrm{Ga}(\mathrm{III})$-Application to the treatment of Bayer liquor. Chem. Eng. J. 2019, 368, 459-473. [CrossRef]

71. Hamza, M.F.; Hamad, N.A.; Hamad, D.M.; Khalafalla, M.S.; Abdel-Rahman, A.A.-H.; Zeid, I.F.; Wei, Y.; Hessien, M.M.; Fouda, A.; Salem, W.M. Synthesis of Eco-Friendly Biopolymer, Alginate-Chitosan Composite to Adsorb the Heavy Metals, Cd(II) and Pb(II) from Contaminated Effluents. Materials 2021, 14, 2189. [CrossRef] [PubMed]

72. Yao, Y.; Gao, B.; Chen, J.; Yang, L. Engineered Biochar Reclaiming Phosphate from Aqueous Solutions: Mechanisms and Potential Application as a Slow-Release Fertilizer. Environ. Sci. Technol. 2013, 47, 8700-8708. [CrossRef]

73. Le Febvrier, A.; Jensen, J.; Eklund, P. Wet-cleaning of MgO: Modification of surface chemistry and effects on thin film growth investigated by x-ray photoelectron spectroscopy and time-of-flight secondary ion mass spectroscopy. J. Vac. Sci. Technol. A Vac. Surf. Film. 2017, 35, 021407. [CrossRef]

74. Dang, L.; Nai, X.; Dong, Y.; Li, W. Functional group effect on flame retardancy, thermal, and mechanical properties of organophosphorus-based magnesium oxysulfate whiskers as a flame retardant in polypropylene. RSC Adv. 2017, 7, 21655-21665. [CrossRef]

75. Jin, T.; He, Y. Antibacterial activities of magnesium oxide (MgO) nanoparticles against foodborne pathogens. J. Nanopart. Res. 2011, 13, 6877-6885. [CrossRef]

76. Shaheen, T.I.; Fouda, A. Green approach for one-pot synthesis of silver nanorod using cellulose nanocrystal and their cytotoxicity and antibacterial assessment. Int. J. Biol. Macromol. 2018, 106, 784-792. [CrossRef]

77. Badawy, A.A.; Abdelfattah, N.A.H.; Salem, S.S.; Awad, M.F.; Fouda, A. Efficacy Assessment of Biosynthesized Copper Oxide Nanoparticles (CuO-NPs) on Stored Grain Insects and Their Impacts on Morphological and Physiological Traits of Wheat (Triticum aestivum L.) Plant. Biology 2021, 10, 233. [CrossRef]

78. Umaralikhan, L.; Jaffar, M. Green Synthesis of MgO Nanoparticles and it Antibacterial Activity. Iran. J. Sci. Technol. Trans. A Sci. 2016, 42. [CrossRef]

79. Hamza, M.F.; Fouda, A.; Elwakeel, K.Z.; Wei, Y.; Guibal, E.; Hamad, N.A. Phosphorylation of Guar Gum/Magnetite/Chitosan Nanocomposites for Uranium (VI) Sorption and Antibacterial Applications. Molecules 2021, 26, 1290. [CrossRef]

80. Nguyen, N.-Y.T.; Grelling, N.; Wetteland, C.L.; Rosario, R.; Liu, H. Antimicrobial Activities and Mechanisms of Magnesium Oxide Nanoparticles (nMgO) against Pathogenic Bacteria, Yeasts, and Biofilms. Sci. Rep. 2018, 8, 16260. [CrossRef]

81. Holm, A.; Vikström, E. Quorum sensing communication between bacteria and human cells: Signals, targets, and functions. Front. Plant Sci. 2014, 5, 309. [CrossRef] 
82. Sawai, J.; Kojima, H.; Igarashi, H.; Hashimoto, A.; Shoji, S.; Takehara, A.; Sawaki, T.; Kokugan, T.; Shimizu, M. Escherichia coli damage by ceramic powder slurries. J. Chem. Eng. Jpn. J. Chem. Eng. Jpn. 1997, 30, 1034-1039. [CrossRef]

83. Dhanasekaran, D.; Thangaraj, R. Evaluation of larvicidal activity of biogenic nanoparticles against filariasis causing Culex mosquito vector. Asian Pac. J. Trop. Dis. 2013, 3, 174-179. [CrossRef]

84. Madhiyazhagan, P.; Murugan, K.; Kumar, A.N.; Nataraj, T.; Dinesh, D.; Panneerselvam, C.; Subramaniam, J.; Mahesh Kumar, P.; Suresh, U.; Roni, M.; et al. S argassum muticum-synthesized silver nanoparticles: An effective control tool against mosquito vectors and bacterial pathogens. Parasitol. Res. 2015, 114, 4305-4317. [CrossRef]

85. Murugan, K.; Jaganathan, A.; Rajaganesh, R.; Suresh, U.; Madhavan, J.; Senthil-Nathan, S.; Rajasekar, A.; Higuchi, A.; Kumar, S.; Alarfaj, A.A.; et al. Poly(Styrene Sulfonate)/Poly(Allylamine Hydrochloride) Encapsulation of TiO2 Nanoparticles Boosts Their Toxic and Repellent Activity Against Zika Virus Mosquito Vectors. J. Clust. Sci. 2017, 29, 27-39. [CrossRef]

86. Murugan, K.; Jaganathan, A.; Suresh, U.; Rajaganesh, R.; Jayasanthini, S.; Higuchi, A.; Kumar, S.; Benelli, G. Towards BioEncapsulation of Chitosan-Silver Nanocomplex? Impact on Malaria Mosquito Vectors, Human Breast Adenocarcinoma Cells (MCF-7) and Behavioral Traits of Non-target Fishes. J. Clust. Sci. 2017, 28, 529-550. [CrossRef]

87. Krishnamoorthy, K.; Manivannan, G.; Kim, S.J.; Jeyasubramanian, K.; Premanathan, M. Antibacterial activity of MgO nanoparticles based on lipid peroxidation by oxygen vacancy. J. Nanopart. Res. 2012, 14, 1063. [CrossRef]

88. Ma, B.; Yu, N.; Han, Y.; Gao, M.; Wang, S.; Li, S.; Guo, L.; She, Z.; Zhao, Y.; Jin, C.; et al. Effect of magnesium oxide nanoparticles on microbial diversity and removal performance of sequencing batch reactor. J Environ. Manag. 2018, 222, 475-482. [CrossRef]

89. Mangalampalli, B.; Dumala, N.; Grover, P. Allium cepa root tip assay in assessment of toxicity of magnesium oxide nanoparticles and microparticles. J. Environ. Sci. 2018, 66, 125-137. [CrossRef]

90. Magdolenova, Z.; Collins, A.; Kumar, A.; Dhawan, A.; Stone, V.; Dusinska, M. Mechanisms of genotoxicity. A review of in vitro and in vivo studies with engineered nanoparticles. Nanotoxicology 2014, 8, 233-278. [CrossRef]

91. Panneerselvam, C.; Murugan, K. Adulticidal, repellent, and ovicidal properties of indigenous plant extracts against the malarial vector, Anopheles stephensi (Diptera: Culicidae). Parasitol. Res. 2013, 112, 679-692. [CrossRef]

92. Mullai, K.; Jebanesan, A.; Pushpanathan, T. Effect of bioactive fractions of Citrullus vulgaris Schrad. leaf extract against Anopheles stephensi and Aedes Aegypti. Parasitol. Res. 2008, 102, 951-955. [CrossRef]

93. Fouda, A.; Khalil, A.; El-Sheikh, H.; Abdel-Rhaman, E.; Hashem, A. Biodegradation and detoxification of bisphenol-A by filamentous fungi screened from nature. J. Adv. Biol. Biotechnol. 2015, 123-132. [CrossRef]

94. White, T.J.; Bruns, T.; Lee, S.; Taylor, J. Amplification and direct sequencing of fungal ribosomal RNA genes for phylogenetics. Pcr Protoc. Guide Methods Appl. 1990, 18, 315-322.

95. Soliman, A.M.; Abdel-Latif, W.; Shehata, I.H.; Fouda, A.; Abdo, A.M.; Ahmed, Y.M. Green Approach to Overcome the Resistance Pattern of Candida spp. Using Biosynthesized Silver Nanoparticles Fabricated by Penicillium chrysogenum F9. Biol. Trace Elem. Res. 2021, 199, 800-811. [CrossRef]

96. Fouda, A.; El-Din Hassan, S.; Salem, S.S.; Shaheen, T.I. In-Vitro cytotoxicity, antibacterial, and UV protection properties of the biosynthesized Zinc oxide nanoparticles for medical textile applications. Microb. Pathog. 2018, 125, 252-261. [CrossRef] [PubMed]

97. Hassan, S.E.; Fouda, A.; Radwan, A.A.; Salem, S.S.; Barghoth, M.G.; Awad, M.A.; Abdo, A.M.; El-Gamal, M.S. Endophytic actinomycetes Streptomyces spp mediated biosynthesis of copper oxide nanoparticles as a promising tool for biotechnological applications. J. Biol. Inorg. Chem. JBIC Publ. Soc. Biol. Inorg. Chem. 2019, 24, 377-393. [CrossRef]

98. Gunathilaka, N.; Ranathunge, T.; Udayanga, L.; Abeyewickreme, W. Efficacy of Blood Sources and Artificial Blood Feeding Methods in Rearing of Aedes aegypti (Diptera: Culicidae) for Sterile Insect Technique and Incompatible Insect Technique Approaches in Sri Lanka. BioMed Res. Int. 2017, 2017, 3196924. [CrossRef] [PubMed] 